\title{
Seasonal and inter-annual variability of energy exchange above a boreal Scots pine forest
}

\author{
S. Launiainen \\ Department of Physics, University of Helsinki, P.O. Box 48, 00014 Helsinki, Finland \\ Finnish Forest Research Institute, Joensuu Research Unit, P.O. Box 68, 80101 Joensuu, Finland
}

Received: 30 June 2010 - Published in Biogeosciences Discuss.: 25 August 2010

Revised: 11 November 2010 - Accepted: 19 November 2010 - Published: 1 December 2010

\begin{abstract}
Twelve-years of eddy-covariance measurements conducted above a boreal Scots pine forest in Hyytiälä, Southern Finland, were analyzed to assess the seasonal and inter-annual variability of surface conductance $\left(g_{\mathrm{s}}\right)$ and energy partitioning. The $g_{\mathrm{s}}$ had distinct annual course, driven by the seasonal cycle of the Scots pine. Low $g_{\mathrm{s}}\left(2-3 \mathrm{~mm} \mathrm{~s}^{-1}\right.$ in April) cause the sensible heat flux to peak in May-June while evapotranspiration takes over later in July-August when $g_{\mathrm{s}}$ is typically $5-7 \mathrm{~mm} \mathrm{~s}^{-1}$. Hence, during normal years Bowen ratio decreases from 4-6 in April to 0.7-0.9 in August. Sensitivity of $g_{\mathrm{s}}$ to ambient vapor pressure deficit $(D)$ was relatively constant but the reference value at $D=1 \mathrm{kPa}$ varied seasonally and between years. Only two drought episodes when volumetric soil moisture content in upper mineral soil decreased below $0.15 \mathrm{~m}^{3} \mathrm{~m}^{-3}$ occurred during the period. Below this threshold value, transpiration was strongly reduced, which promoted sensible heat exchange increasing Bowen ratio to 3-4. Annual evapotranspiration varied between 218 and $361 \mathrm{~mm}$ and accounted between 50\% and $90 \%$ of equilibrium evaporation. The forest floor contributed between 16 and $25 \%$ of the total evapotranspiration on annual scale. The fraction stayed similar over the observed range of environmental conditions including drought periods. The inter-annual variability of evapotranspiration could not be linked to any mean climate variable while the summertime sensible heat flux and net radiation were well explained by global radiation. The energy balance closure varied annually between 0.66 and 0.95 and had a distinct seasonal cycle with worse closure in spring when a large proportion of available energy is partitioned into sensible heat.
\end{abstract}

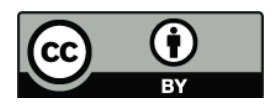

Correspondence to: S. Launiainen (samuli.launiainen@metla.fi)

\section{Introduction}

The earth's climate is driven by the solar radiation absorbed at the surface. Based on the principle of energy conservation, this primary energy input is redistributed in radiative, turbulent and conductive heat transfer between the atmosphere and the surface. The partitioning of net radiation $\left(R_{\mathrm{n}}\right)$ to sensible $(H)$ and latent heat fluxes (LE) has a critical role in atmospheric boundary layer (ABL) dynamics such as the daily cycle of ABL height, entrainment of dry air, cloud development and, hence, directly influences local and regional climate. Changes in local environmental conditions, such as temperature $(T)$, vapor pressure deficit $(D)$ and soil moisture availability affect a variety of physical and physiological processes in plant canopies. These changes may also significantly alter the greenhouse gas budgets of vegetated ecosystems, forming a direct link to global climate (e.g. Chapin et al., 2000). Boreal coniferous forests are of particular importance because of their large extent and presumed sensitivity to projected climate changes at high latitudes (Chapin et al., 2000; Eugster et al., 2000). According to climate scenarios, the mean annual air temperatures in Northern Europe are expected to increase between 2 and $6{ }^{\circ} \mathrm{C}$ during this century and the increase is likely to be strongest during winter months (Christensen et al., 2007).

Boreal forests cover an area around 12.0-14.7 million square kilometers in the circumpolar region between 50 and $70^{\circ} \mathrm{N}$ making it the second largest forest biome (Baldocchi et al., 2000). The boreal forests are dominated by coniferous species, which have lower albedo and hence absorb more radiation than deciduous forests (Jarvis and McNaughton, 1986; Baldocchi et al., 2000). Also, boreal conifers follow very conservative water use strategies; even in ample soil moisture availability the transpiration rate is reduced

Published by Copernicus Publications on behalf of the European Geosciences Union. 
by stomata when the foliage is exposed to high ambient $D$. Consequently, the ABL grows typically higher above a landscape dominated by coniferous forests. The evergreen conifers are able to photosynthesize and transpire at low rates in late winter and spring whenever the air temperature rises markedly above zero for a few days (e.g. Arneth et al., 2006; Sevanto et al., 2006). However, the speed of recovery from winter dormancy significantly alters assimilation and transpiration rates of the conifers in spring (Mäkelä et al., 2004; Arneth et al., 2006; Hari and Kulmala, 2008), which may strongly influence the energy partitioning at these ecosystems. Thus, in terms of surface energy balance, the seasonal cycle of evergreen boreal coniferous trees has analogies to the budburst and leaf growth of deciduous vegetation, both dramatically affecting the energy partitioning.

The eddy-covariance (EC) method provides a direct measure of the energy exchange and its temporal variability in timescales ranging tens of minutes to annual and decadal (Baldocchi, 2008). During the last decade there has been a wealth of studies on energy exchange from various ecosystems, including syntheses of several FluxNet-sites (Law et al., 2002; Wilson et al., 2002a; Baldocchi, 2008). Although many of these studies have indicated considerable seasonal and year-to-year changes in surface energy budget, the studies concentrating particularly on inter- and intra-annual variability on boreal coniferous forests are surprisingly scarce (Tchebakova et al., 2002; Arain et al., 2003; Grünwald and Bernhofer, 2007; Amiro et al., 2006). Long-term studies could, however, reveal the influence of various disturbances, forest management practices, and climate variability on the surface-atmosphere energy and water vapor exchange.

Motivated by the scarcity of long-term studies of boreal coniferous forest energy exchange, this paper focuses to the temporal variability in the energy fluxes of a boreal Scots pine forest, from diurnal to inter-annual scales. It uses the continuous EC measurements made above the canopy for twelve successive years (1997-2008) and in trunk-space from 2004 at SMEAR II-station in Hyytiälä, Southern Finland, one of the most intensively studied sites in the boreal region. The EC-measurements at the site started in April 1996 and carbon dynamics and its seasonal and inter-annual variability have been studied by several authors (Markkanen et al., 2001; Suni et al., 2003; Vesala et al., 2005) and synthesized recently by Kolari et al. (2009). The energy fluxes, on the other hand, have received far less attention and have been discussed only as far as has been compulsory for understanding the carbon fluxes and their controlling mechanisms (Markkanen et al., 2001; Suni et al. 2003), transpiration and sap flow dynamics (Sevanto et al., 2006) or evapotranspiration (ET) as a component of water balance (Ilvesniemi et al., 2010). Among the FluxNet-sites, Hyytiälä is classified as evergreen needle-leaf forest and its annual gross-primary production (GPP) varies between 970 and $1120 \mathrm{~g} \mathrm{C} \mathrm{m}^{-2}$ and ecosystem respiration (TER) from 800 to $860 \mathrm{~g} \mathrm{C} \mathrm{m}^{-2}$ (Kolari et al., 2009). The mean ecosystem level water use ef- ficiency (WUE $=\mathrm{GPP} / \mathrm{ET}$ ) is $3.61 \mathrm{~g} \mathrm{C}\left(\mathrm{kg} \mathrm{H}_{2} \mathrm{O}\right)^{-1}$ (Beer et al., 2009), all rather typical values for this vegetation type in boreal region.

The study aims to: (1) describe the typical characteristics of the energy fluxes and their variability from diurnal to interannual timescales, (2) consider the partitioning of evapotranspiration (ET) and sensible heat flux between the crown and forest floor components, (3) examine the seasonal and interannual variability of energy balance closure and (4) assess the roles of stomatal regulation - its seasonality, environmental responses and triggers - and climate variability on energy partitioning.

\section{Materials and methods}

\subsection{The site}

SMEAR II station is located in a relatively homogenous Scots pine stand (Pinus sylvestris L.) sown in 1962 next to the Hyytiälä forest station of the University of Helsinki in Southern Finland $\left(61^{\circ} 51^{\prime} \mathrm{N}, 24^{\circ} 17^{\prime} \mathrm{E}, 181 \mathrm{~m}\right.$ a.s.l.). Mean canopy height $\left(h_{\mathrm{c}}\right)$ increased from 13 to $16 \mathrm{~m}$ during the twelve-year period (1997-2008) analyzed in this paper. In year 2001 , the stem density was $\approx 1800 \mathrm{ha}^{-1}$ but between January and March 2002 most of the stand was thinned to density of $1000-1200 \mathrm{ha}^{-1}$, resulting in about $27 \%$ reduction in tree biomass and foliage area (Vesala et al., 2005; Ilvesniemi et al., 2010). Consequently, total (two-sided) leaf area index (LAI) dropped from 8 to $6 \mathrm{~m}^{2} \mathrm{~m}^{-2}$ (annual average) but the earlier level was rapidly re-established in a few years. Moreover, the Scots pines at the site have four needle cohorts; the new needles are developed in June-July and the oldest cohort senesces in August creating $\approx 25 \%$ seasonal variability to LAI. The site is described in micrometeorological context in Rannik (1998) who estimated the displacement height and the roughness length for momentum to be $0.78 h_{\mathrm{c}}$ and $0.062 h_{\mathrm{c}}$, respectively.

The forest floor (understory and soil) beneath the relatively open main pine canopy is well coupled to the atmosphere and contributes significantly to forest scale carbon (Kolari et al., 2006) and energy exchange (Launiainen et al., 2005). In daytime, the turbulence is relatively intense all the way down to the forest floor (Launiainen et al., 2007), which efficiently smoothes the vertical gradients of $\mathrm{CO}_{2}, \mathrm{H}_{2} \mathrm{O}$ and temperature within the forest. The shortwave radiation received at the forest floor is typically $20-30 \%$ of that above the canopy, depending on sun elevation and ratio of diffuse to direct radiation (Kolari et al., 2006). The forest floor vegetation is dominated by lingonberry (Vaccinium vitis-idaea), blueberry (Vaccinium myrtillus) and mosses, mainly Pleurozium schreberi and Dicranum polysetum. In $2005,30 \%$ of the dry biomass was lingonberry, $19 \%$ blueberry and 35\% mosses (Kulmala et al., 2008). The total LAI of the shrubs is about $0.5 \mathrm{~m}^{2} \mathrm{~m}^{-2}$ and the mosses $1.0 \mathrm{~m}^{2} \mathrm{~m}^{-2}$ (L. Kulmala, 
personal communication, 2009). The mosses had total percentage cover of about $60 \%$ overlying a $5 \mathrm{~cm}$ organic humus layer (Kolari et al., 2006). The soil is a Haplic podzol on glacial till (FAO-Unesco, 1990).

\subsection{Measurements of the energy balance components}

The surface energy balance over tall vegetation can be expressed as

$R_{\mathrm{n}}=H+\mathrm{LE}+G+Q_{\mathrm{h}}+Q_{\mathrm{e}}+Q_{\mathrm{b}}+Q_{\mathrm{p}}$,

where $R_{\mathrm{n}}$ is the net radiation, $H$ and LE the sensible and latent heat fluxes, respectively, and $G$ the heat flux into the soil. The $Q_{\mathrm{h}}$ and $Q_{\mathrm{e}}$ are the rate of change in sensible and latent heat storage between the surface and the reference level, $Q_{\mathrm{b}}$ the amount of energy stored into the above-ground biomass and $Q_{\mathrm{p}}$ the energy consumed in photosynthesis. All terms in Eq. (1) have units of $\mathrm{W} \mathrm{m}^{-2} . R_{\mathrm{n}}$ and $G$ are defined positive downwards as are increase of storages. The sign convention is opposite for turbulent fluxes. During periods with snow cover, in particular during freezing/thawing events, the energy balance equation must also include terms describing the snow processes that were, unfortunately, not measured in sufficient detail. Therefore, the energy balance analysis is restricted to snow-free period (May-October).

Net radiation was measured at the top of the tower $(70 \mathrm{~m})$ with a Reemann MB-1 net-pyrradiometer (Astrodata, Estonia). EC measurements of the turbulent fluxes ( $H$ and LE) were made at $23.3 \mathrm{~m}$ height (7-10 $\mathrm{m}$ above canopy top) except for the period from 1/1999 to 6/2000 when the measurement height was $46 \mathrm{~m}$. The measurement setup consisted of a 3-D ultrasonic anemometer (Solent Research 1012R2, Gill Ltd., Lymington, Hampshire, England) to measure the three wind speed components and sonic temperature and a closedpath infrared gas analyser (LI-6262, LiCor Inc., Lincoln, NE, USA) to measure $\mathrm{CO}_{2}$ and $\mathrm{H}_{2} \mathrm{O}$ mixing ratios at $21 \mathrm{~Hz}$ frequency. Air samples were drawn through a $7 \mathrm{~m}$ long (the outside/inside diameter is $6 / 4 \mathrm{~mm}$ ) heated tubing at a flow rate of $6.1 \mathrm{~L} \mathrm{~min}^{-1}$. Originally, the tube was entirely PTFE Teflon but was replaced in May 2002 with an electro polished seamless stainless steel tube. Two-point (zero and 400-500 ppm) in situ calibrations were routinely done for the gas-analyzer every three months indicating typically less than $2 \%$ span drift, which was assumed to be linear between the calibrations. Once a year the gas-analyzer was serviced and calibrated in a laboratory. A $1.0 \mu \mathrm{m}$ pore size membrane filter (Gelman Acro 50, PTFE element, polypropylene support plate and housing, Pall Corporation, East Hills, NY, USA) recommended by LiCor Inc., was used at the inlet of the LI6262 analyser to keep its measurement cell clean. The filter was replaced whenever the pressure drop had increased to about double of the initial value with a clean filter or if the pressure drop was showing a dependence on ambient relative humidity and/or was not stable over a day. The frequency of the filter change varied from a few weeks to about 2 months.
The $1 / 2 \mathrm{~h}$ average turbulent fluxes of momentum and sensible $(H)$ and latent heat (LE) were calculated using standard methodology (Aubinet et al., 2000). First, the raw data was de-spiked using predefined upper and lower limits for acceptable values and then a 3-D co-ordinate rotation was applied. Time lags between vertical wind speed and $\mathrm{CO}_{2-}$ and $\mathrm{H}_{2} \mathrm{O}$-mixing ratios were taken into account using the maximum (absolute) covariance method. Fluxes were corrected for high and low frequency losses, due to the limited temporal resolution of the EC system and the finite time averaging period, using co-spectral transfer function method (Laubach and McNaughton, 1999). For $\mathrm{H}_{2} \mathrm{O}$ and $\mathrm{CO}_{2}$-fluxes, an empirical method for determining the first-order response time of the whole system (Aubinet et al., 2000) was used while the sensible heat and momentum fluxes were corrected according to the theoretical transfer functions (Moore, 1986). Recently, Mammarella et al. (2009) showed that the performance of the EC-setup for detecting $\mathrm{H}_{2} \mathrm{O}$-fluctuations deteriorated with increasing ambient relative humidity $(\mathrm{RH})$ and ageing of the sample tube, proposing a method for accounting of this effect. Here the $\mathrm{H}_{2} \mathrm{O}$ fluxes were corrected accordingly for years 2001-2008. The correction was, however, not applied for 1997-2000, during which the measurement height, measurement configuration and calibration intervals were changing (see Markkanen et al., 2001 for details). In near-neutral conditions $80 \%$ of the scalar fluxes originate, depending on upwind topography, between 200 and $300 \mathrm{~m}$ upwind from the measurement mast (Sogachev et al., 2004). In near-neutral and unstable stratification the footprint is rather homogenous. However, according to Göckede et al. (2008), the representativity of EC fluxes at the Hyytiälä site is reduced in stable stratification due to low turbulence and existing heterogeneities within the large source area. This should be taken into account along the instrumental problems (anemometer freezing, tube condensation) and large relative errors associated with wintertime flux EC measurements. A more complete description of the EC-measurement setup at SMEAR II-site is given in Mammarella et al. (2009).

In 2005-2007, $G$ was estimated from ground heat flux measurements made at $10 \mathrm{~cm}$ depth by three Hukseflux HFP01SC heat flux plates (Hukseflux Thermal Sensors, Netherlands), corrected for the change of the heat storage at the soil layer above the measurement depth according to Ochsner et al. (2007). Before $2005 G$ was not directly measured and therefore estimated as the rate of the change of the soil heat storage in the top $75 \mathrm{~cm}$ of soil accounting for the changes in soil heat capacity due to changes in volumetric soil moisture content $(\theta) . \quad Q_{\mathrm{a}}$ and $Q_{\mathrm{e}}$ were estimated from four-level $(4.2,8.4,16.8,33.6 \mathrm{~m})$ temperature (ventilated and radiation shielded PT- 100 sensors) and $\mathrm{H}_{2} \mathrm{O}$ profile measurements (URAS $4 \mathrm{H}_{2} \mathrm{O}$, Hartmann \& Braun, Frankfurt am Main, Germany), respectively. The profile measurements are described in Rannik et al. (2004). The scalar values at the ground were assumed to be the same as at the lowest 
measurement level and the values at EC measurement height was taken to be the geometric mean of the closest level below and above it. The heat storage into the biomass was calculated separately for the needles and trunks using within and below canopy air temperature $\left(T_{\mathrm{a}}, 8.4\right.$ and $\left.4.2 \mathrm{~m}\right)$ as a surrogate for the biomass temperatures, which were not continuously measured. The comparison of the available data showed that the average bole temperature lagged the air temperature by $\approx 2 \mathrm{~h}$ and had average diurnal amplitude of 0.65 times the one for air temperature, which were taken into account in the calculations. The needle temperature was assumed to follow $T_{\mathrm{a}}$. $Q_{\mathrm{p}}$ was estimated from the measured $\mathrm{CO}_{2}$-flux for periods of net $\mathrm{CO}_{2}$-uptake (Blanken et al., 1997). All of the methods used in this study are typical for energy balance studies carried out in forest ecosystems and the equations for storage flux calculations can be found, for instance, in Oliphant et al. (2004).

\subsection{Auxillary measurements}

In addition to the measurements listed before, the following data were used: humus and soil temperature $\left(T_{\mathrm{h}}, T_{\mathrm{S}}\right)$ were measured by silicon temperature sensors (Phillips KTY81110) and the volumetric moisture content $\left(\theta, \mathrm{m}^{3} \mathrm{~m}^{-3}\right)$ by time domain reflectometer (Tektronix 1502C, Tektronix Inc. and TDR100, Campbell Scientific) at $2 \mathrm{~cm}$ (humus) and between 5 and $25 \mathrm{~cm}$ (mineral soil) depths. Global radiation $\left(R_{\mathrm{g}}\right)$ was measured by Reeman TP 3 pyranometers (Astrodata, Estonia) and photosynthetic photon flux density (PAR, $\mu \mathrm{mol} \mathrm{m} \mathrm{m}^{-2} \mathrm{~s}^{-1}$ ) by LI-190SZ quantum sensor (LiCor Inc., Lincoln, NE, USA) at $22 \mathrm{~m}$ height on the top of a scaffolding tower. $R_{\mathrm{g}}$ was not measured in 1998 but was calculated from PAR using linear regression determined using data from 1997 and 1999. Precipitation was measured above the forest using tipping bucket rain gauge (ARG-100, Vector Instruments, Rhyl, Clwyd, UK) and aggregated to $1 / 2 \mathrm{~h}$ sums. The tipping bucket measurements are biased in wintertime when most of the precipitation is falling as snow and therefore the annual precipitation numbers were taken from a weather station operated by the Finnish Meteorological Institute located about $600 \mathrm{~m}$ west from the SMEAR II site. Precipitation data along with the rain detector readings (DRD 11-A, Vaisala, Vantaa, Finland) were used to separate wet and dry canopy conditions. Later, $T_{\mathrm{a}}$ and vapor pressure deficit $(D)$ refer to values at $8.4 \mathrm{~m}$ height.

\subsection{Gap-filling the time series}

Data gaps are unavoidable in long-term measurements and are caused by instrumental or methodological issues such as insufficient turbulent mixing, which can bias the EC estimates. In carbon flux studies the (nighttime) periods with low friction velocity $\left(u_{*}\right)$ are typically rejected and filled using data collected in more turbulent conditions. For the energy fluxes, $H$ in particular, this method could introduce systematic error since the stability on the surface layer, and hence the degree of turbulent mixing, is directly influenced by the sensible heat flux (and vice versa). Thus, replacing low $u_{*}$ periods with higher $u_{*}$ may lead to biased estimate of $H$. Therefore, the $u_{*}$-filtering was not used but only periods when storage terms were available were considered. To provide annual balances, the gaps in $R_{\mathrm{n}}, H, \mathrm{LE}$ and $G$ time series were filled using a combination of look-up tables and mean diurnal variability according to the method proposed by Reichstein et al. (2005). The gaps in meteorological and soil data were filled either by linear interpolation or by the mean diurnal variability determined in a 14-day moving window. On the annual scale between $7 \%$ (2008) and $18 \%$ (1997) of $H, 7 \%$ (2008) and 27\% (2005) of LE and $4 \%$ (2008) to $26 \%$ (1999) of $R_{\mathrm{n}}$ data had to be gap-filled. Majority of gaps result from instrumental problems during wintertime and occasional power breaks caused by thunderstorms.

\subsection{Data-analysis}

The bulk surface conductance for water vapor $\left(g_{\mathrm{s}}, \mathrm{m} \mathrm{s}^{-1}\right)$ was estimated by inverting the Penman-Monteith equation (e.g. Monteith and Unsworth, 2008)

$$
\mathrm{LE}=\frac{s R_{\mathrm{a}}+\rho c_{p} D g_{\mathrm{a}}}{s+\gamma\left(1+g_{\mathrm{a}} / g_{\mathrm{s}}\right)},
$$

yielding

$$
\frac{1}{g_{\mathrm{s}}}=\frac{1}{g_{\mathrm{a}}}\left(\frac{\varepsilon R_{\mathrm{a}}+\rho c_{p} g_{\mathrm{a}} D / \gamma}{\mathrm{LE}}-\varepsilon-1\right) .
$$

Here $R_{\mathrm{a}}$ is the available energy $\left(R_{\mathrm{a}}=R_{\mathrm{n}}-G-\sum Q_{i}\right.$, $\left.\mathrm{W} \mathrm{m}{ }^{-2}\right), g_{\mathrm{a}}$ the aerodynamic conductance $\left(\mathrm{m} \mathrm{s}^{-1}\right), s$ is the slope of saturation vapor pressure curve $\left(\mathrm{Pa} \mathrm{K}^{-1}\right)$ and $\gamma$ the psychrometric constant $\left(\mathrm{Pa} \mathrm{K}^{-1}\right), \varepsilon=s / \gamma, \rho$ the air density $\left(\mathrm{kg} \mathrm{m}^{-3}\right), c_{p}$ the heat capacity of the air in constant pressure $\left(\mathrm{J} \mathrm{kg}^{-1} \mathrm{~K}^{-1}\right), D(\mathrm{~Pa})$ the vapor pressure deficit and LE the measured latent heat flux (in $\mathrm{W} \mathrm{m}^{-2}$ ). In the above form of the Eq. (3) $g_{\mathrm{s}}$ is denoted separately from the aerodynamic conductance. The bulk aerodynamic resistance $\left(r_{\mathrm{a}}=1 / g_{\mathrm{a}}\right)$ was estimated by accounting the excess resistance to heat and mass transfer as:

$r_{\mathrm{a}}=r_{\mathrm{a}, \mathrm{m}}+r_{\mathrm{b}}=\bar{u} / u_{*}^{2}+k B^{-1} / k u_{*}$,

where $k$ is the von Karman constant, $r_{\mathrm{a}, \mathrm{m}}$ the aerodynamic resistance for momentum transfer and $r_{\mathrm{b}}$ the quasi-laminar boundary-layer resistance. Here I used a value $k B^{-1}=2$, a representative value for this type of forest (Verma, 1989). For the period 1/1999 to $6 / 2000$, when the flux measurement height was $46 \mathrm{~m}$, the wind speed at $23.3 \mathrm{~m}$ height $(\bar{u})$ was approximated assuming logarithmic gradient between 16.8 and $33.6 \mathrm{~m}$ levels.

The decoupling coefficient $(\Omega)$ explains the degree of coupling between the atmosphere and the vegetation. It ranges from 0 (LE is controlled by stomatal conductance through its 

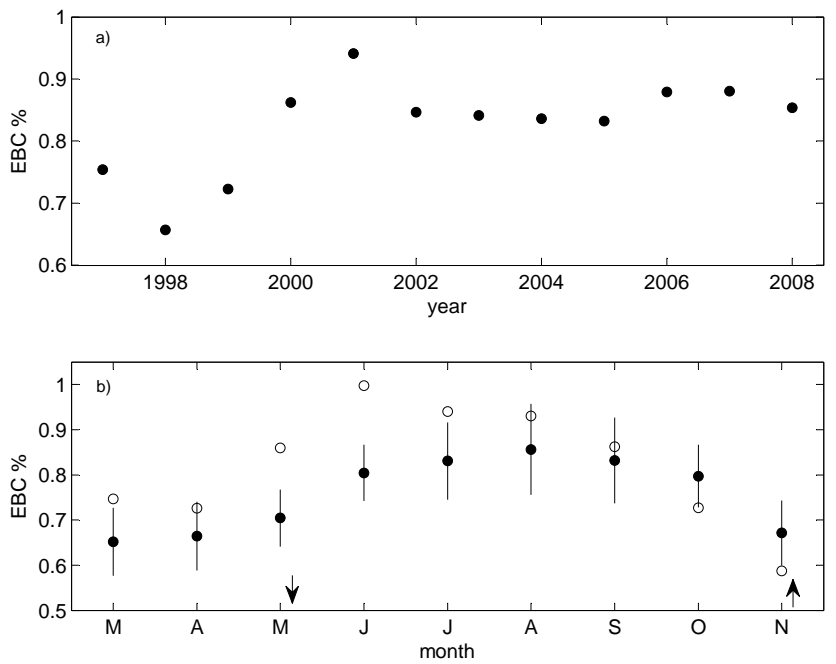

Fig. 1. Energy balance closure (EBC) above the forest: (a) annual (May-October) closures (b) monthly averages for MarchNovember period (mean \pm std, black circles) and seasonal course for year 2001 that had the best annual closure (0.95, open circles). The arrows indicate the time of latest snow melt and earliest snow fall during 1997-2008.

response to $D$, i.e. physiological control) to unity (LE is controlled by the available energy) and was calculated as (Jarvis and McNaughton, 1986):

$\Omega=\frac{\varepsilon+1}{\varepsilon+1+\frac{g_{\mathrm{a}}}{g_{\mathrm{s}}}}$

Equilibrium evaporation $\left(\mathrm{LE}_{\mathrm{eq}}\right)$ is the climatologically determined evaporation (atmospheric demand) over an extensive wet surface defined as (Monteith and Unsworth, 2008):

$\mathrm{LE}_{\mathrm{eq}}=\frac{s R_{\mathrm{a}}}{s+\gamma}$.

The effective surface parameters defined by Eqs. (3-6) were used to characterize the seasonal and inter-annual variability of evapotranspiration (ET), its controlling mechanisms and causes in the big-leaf framework, an appropriate scale to analyze the eddy-covariance measurements.

\section{Results}

\subsection{Energy balance closure}

The energy balance closure ratio (EBC) was evaluated as a slope of the linear least square regression between the $1 / 2 \mathrm{~h}$ turbulent fluxes $(H+\mathrm{LE})$ and $R_{\mathrm{a}}$ for each year and month separately. The closure during the snow free period (MayOctober) varied between 0.66 (1998) and 0.95 (2001) and the intercepts between $-6.5 \mathrm{~W} \mathrm{~m}^{-2}$ (2008) and $+13.1 \mathrm{~W} \mathrm{~m}^{-2}$ (1997). The annual EBC and its seasonal dynamics are shown in Fig. 1. It appears that the first three years, from
1997 to 1999 , have significantly poorer energy balance closure and degree of explained variance $\left(R^{2}=0.71-0.86\right)$ than the latter years $\left(R^{2}=0.87-0.90\right)$. In addition, there was marked seasonality in EBC with poorer closure during winter months $(\approx 0.50$, not shown) and spring (0.65-0.7, March-May) than summertime, particularly in late summer. In 2001, when EBC was best, the closure in May-July was markedly better than on average.

\subsection{Climate conditions}

The climate in Finland has both maritime and continental characteristics depending on the prevailing direction of the air flow. In wintertime, received solar radiation is low due to the northern location of the site $\left(61^{\circ} 51^{\prime} \mathrm{N}\right)$. The winter temperatures are, however, much higher (up to 10-20 K) than at other areas at these latitudes such as Siberia or Central Alaska, because the prevailing westerlies bring warm and moist air from the North Atlantic Gulf stream region. At times, the Asian continental climate extends to Finland causing extremely cold spells during the winter and warm and dry conditions in summertime. Because of these constraints, weather in Finland is sensitive to changes in the locations and relative strengths of the North Atlantic low and the high pressure systems located at the Azores and over Siberia. In the 1970 to 2000 period the mean annual temperature at the site was $+3.3{ }^{\circ} \mathrm{C}$ and precipitation $713 \mathrm{~mm}$. The coldest and warmest months are February $\left(-7.8^{\circ} \mathrm{C}\right)$ and July $\left(+15.5^{\circ} \mathrm{C}\right)$, which are also the driest and wettest (34 and $94 \mathrm{~mm}$ of precipitation, respectively) (Drebs et al., 2002). The duration and thickness of the snow cover varies annually but normally the permanent snow falls in the latest weeks of November (earliest 5 November in 1998, latest 16 January 2007), the snowpack is thickest in February to mid-March and melts rapidly in late March-April. The final snowmelt occurs from the open areas around 20 April; the earliest date was in 2007 (28 March) and latest in 1997 (5 May). In winters when south-westerly winds are strong, there can exist several incomplete freeze-thaw cycles of the snowpack in response to synoptic scale weather changes.

Figure 2 shows climate characteristics during the studied period, 1997-2008. For clarity, the range, mean and few selected years are shown and all values represent 30-day running averages. Mean annual and July-August values are also reported in Tables 1 and 2, respectively. The most prominent features in Fig. 2 are that: (1) along the typical annual course of $R_{\mathrm{g}}, T_{\mathrm{a}}$ and $D$ there is considerable inter-annual variability (IAV) in particularly in summertime $R_{\mathrm{g}}, D$ and soil moisture $(\theta)$. (2) Occurrence of the highest $D$ varies from early June to late August depending on the year and the monthly mean $D$ reaches $0.75-1 \mathrm{kPa}$ at maximum. (3) Inter-annual variability of $T_{\mathrm{a}}$ is greatest in wintertime (up to $15 \mathrm{~K}$ in January) while in summer the IAV is typically less than $4{ }^{\circ} \mathrm{C}$. (4) Soil moisture has its maximum (saturated) value $\left(\approx 0.40-0.45 \mathrm{~m}^{2} \mathrm{~m}^{-2}\right)$ in springtime after the snowmelt and is thereafter consumed by 

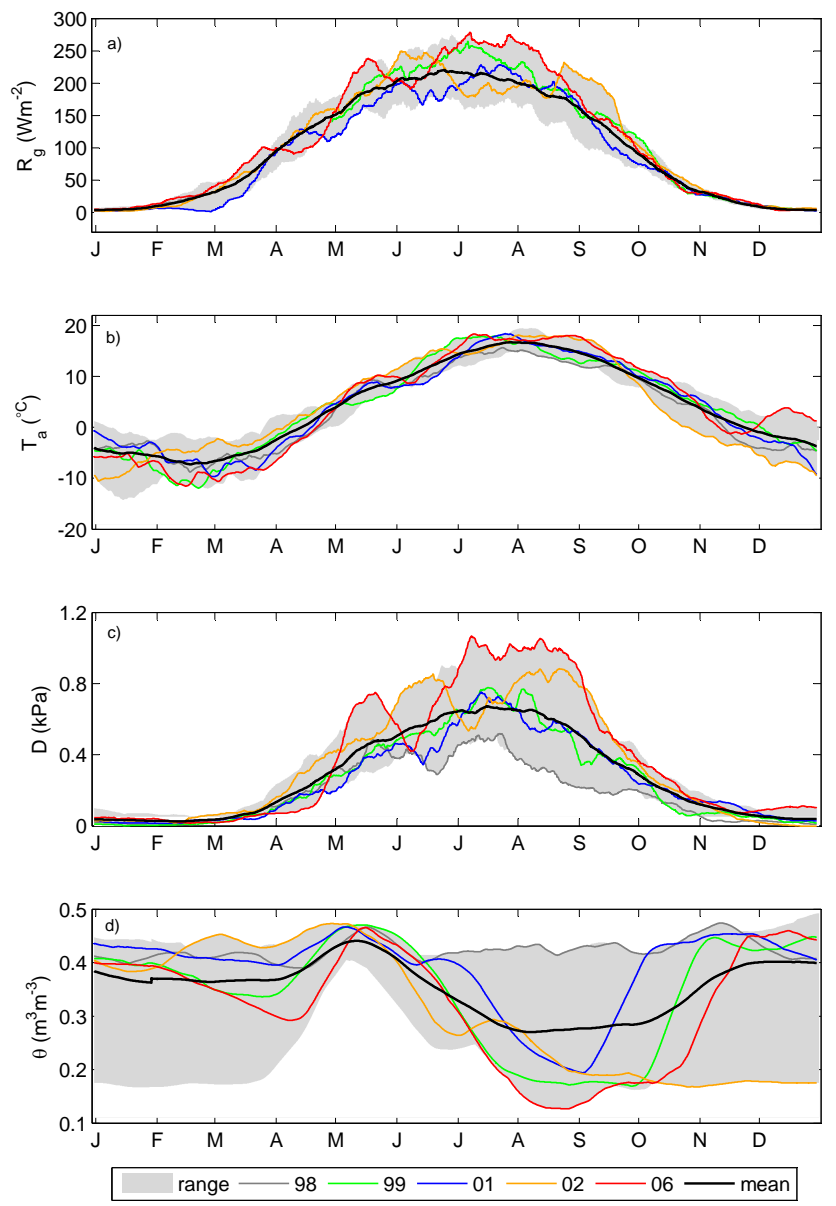

Fig. 2. Seasonal course of (a) global radiation $\left(R_{\mathrm{g}}\right)$, (b) air temperature $\left(T_{\mathrm{a}}\right),(\mathbf{c})$ vapor pressure deficit $(D)$ and $(\mathbf{d})$ volumetric soil moisture content at $5-25 \mathrm{~cm}$ depth $(\theta)$. All data are 30-day running means. The grey area corresponds to the variability range of the 30day running means during 1998-2008 while the average is given by the thick black line.

transpiration and reaches the minimum $\left(0.15-0.20 \mathrm{~m}^{2} \mathrm{~m}^{-2}\right)$ normally in August before re-charge in autumn. Years 1999, 2002 and 2006 had lowest late summer $\theta\left(<0.15 \mathrm{~m}^{2} \mathrm{~m}^{-2}\right)$. The rate of soil water storage depletion is strongly influenced by the precipitation. For instance, the 1998 summer was exceptionally cloudy and the accumulated precipitation (MayAugust) was $437 \mathrm{~mm}$, about $150 \mathrm{~mm}$ higher than typical, and only minor decrease in $\theta$ was observed during the summer. The other anomalies were 2002 when autumn was extremely dry and $\theta$ remained low until the next spring and 2003 when minimum $\theta$ was not reached until late September.

In terms of climate, the extreme growing seasons were cloudy and moist 1998 and warm and dry 2006. In addition, summer 1998 and 2000 (not shown) were characterized by low $D$ and early autumn 2002 by very dry and cloudless conditions.
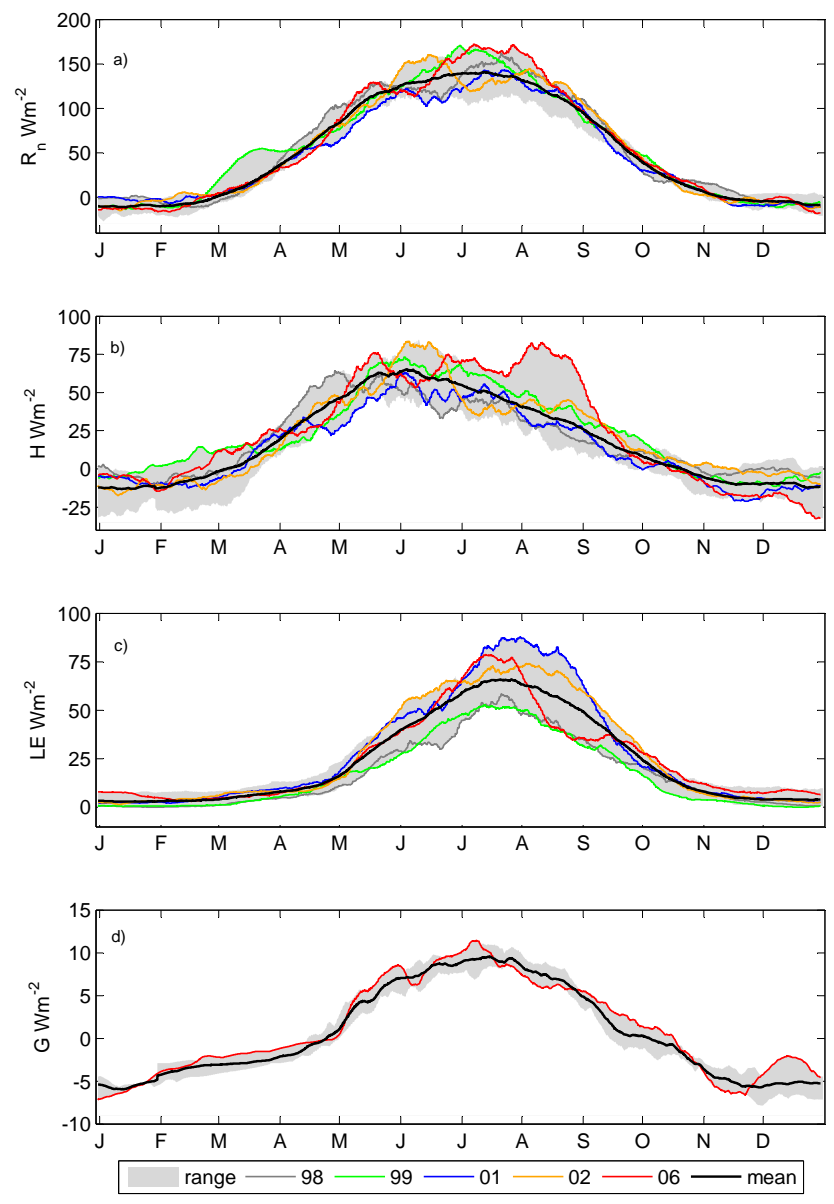

Fig. 3. Seasonal course of main energy balance terms: (a) net radiation $\left(R_{\mathrm{n}}\right)$, (b) sensible heat flux $(H)$, (c) latent heat flux (LE) and (d) heat flux into the soil $(G)$. All data are 30-day running means. The grey area corresponds to the variability range of the 30-day running means during 1998-2008 while the average is given by the thick black line. $G$ was not explicitly measured before year 2006 . The $R_{\mathrm{n}}$ and $G$ are defined positive downwards while the sign convention is opposite for $H$ and LE.

\subsection{Seasonal and diurnal courses}

Seasonal and inter-annual variability of the main energy balance components (Eq. 1) are shown in Fig. 3 using 30day running averages. The mean diurnal courses for selected months in a typical year (2007) are presented in Fig. 4 and the storage fluxes for July, the month they are at their largest, are given in Fig. 5. The seasonal course of $R_{\mathrm{n}}$ follows primarily the incoming solar radiation $\left(R_{\mathrm{g}}\right.$, Fig. 2$)$ and is modified by effective long-wave cooling, which depends on the degree of cloud cover and temperature. The winter half of the year (November-February) is characterized by stable or near-neutral stratification - negative or nearzero $R_{\mathrm{n}}$. Consequently, the sensible heat flux is directed downwards to balance the net radiation deficit, particularly in nighttime (Figs. 3 and 4). During these months the typical 
Table 1. Annual energy fluxes and mean climate characteristics over 1997-2008 period: $R_{\mathrm{g}}$ and $R_{\mathrm{n}}$ are global and net radiation, $H$, LE and $G$ sensible, latent and soil heat fluxes. EBC is the energy balance closure ratio, Precip and ET annual precipitation and evapotranspiration, $\mathrm{ET}_{\mathrm{eq}}$ the equilibrium evaporation (Eq. 6), $\beta$ Bowen ratio (H/LE), $T_{\mathrm{a}}$ and $T_{\mathrm{S}}$ air and soil temperatures, $D$ vapor pressure deficit and $U$ mean wind speed. Values marked with * should be interpreted with care because the LE values in 1997-1999 are likely to be underestimates.

\begin{tabular}{|c|c|c|c|c|c|c|c|c|c|c|c|c|c|c|}
\hline & $1997^{*}$ & $1998^{*}$ & $1999^{*}$ & 2000 & 2001 & 2002 & 2003 & 2004 & 2005 & 2006 & 2007 & 2008 & mean & std \\
\hline$R_{\mathrm{g}}\left(\mathrm{MJ} \mathrm{m}^{-2} \mathrm{a}^{-1}\right)$ & 3453 & 2981 & 3068 & 3100 & 2940 & 3417 & 2927 & 2829 & 3071 & 3593 & 3524 & 2783 & 3141 & 282 \\
\hline$R_{\mathrm{n}}\left(\mathrm{MJ} \mathrm{m}^{-2} \mathrm{a}^{-1}\right)$ & 1706 & 1781 & 1857 & 1647 & 1558 & 1757 & 1580 & 1541 & 1683 & 1794 & 1652 & 1675 & 1686 & 99 \\
\hline$H\left(\mathrm{MJ} \mathrm{m}^{-2} \mathrm{a}^{-1}\right)$ & 653 & 602 & 744 & 650 & 445 & 652 & 517 & 468 & 600 & 729 & 511 & 397 & 581 & 112 \\
\hline $\operatorname{LE}\left(\mathrm{MJ} \mathrm{m}^{-2} \mathrm{a}^{-1}\right)$ & $744^{*}$ & $542^{*}$ & $532 *$ & 691 & 882 & 856 & 792 & 733 & 741 & 783 & 864 & 842 & 750 & 116 \\
\hline$G\left(\mathrm{MJ} \mathrm{m}^{-2} \mathrm{a}^{-1}\right)$ & & & & & & & & & 28 & 36 & 9 & 3 & 19 & 16 \\
\hline $\mathrm{EBC}$ & $0.75^{*}$ & $0.65^{*}$ & $0.71^{*}$ & 0.80 & 0.91 & 0.83 & 0.81 & 0.80 & 0.82 & 0.86 & 0.87 & 0.84 & 0.80 & 0.07 \\
\hline Precip (mm) & 683 & 825 & 676 & 725 & 751 & 535 & 645 & 718 & 698 & 644 & 699 & 903 & 709 & 92 \\
\hline $\mathrm{ET}(\mathrm{mm})$ & $305^{*}$ & $222^{*}$ & $218^{*}$ & 283 & 361 & 350 & 324 & 300 & 303 & 320 & 354 & 345 & 307 & 47 \\
\hline $\mathrm{ET}_{\mathrm{eq}}(\mathrm{mm})$ & 435 & 434 & 461 & 410 & 394 & 459 & 409 & 387 & 415 & 457 & 420 & 406 & 424 & 25 \\
\hline$\beta$ (annual) & $0.88^{*}$ & $1.11^{*}$ & $1.40^{*}$ & 0.94 & 0.50 & 0.76 & 0.65 & 0.64 & 0.81 & 0.93 & 0.59 & 0.47 & 0.81 & 0.27 \\
\hline ET/Precip & $0.45^{*}$ & $0.27^{*}$ & $0.32^{*}$ & 0.39 & 0.48 & 0.65 & 0.50 & 0.42 & 0.43 & 0.50 & 0.51 & 0.38 & 0.44 & 0.10 \\
\hline$\alpha=\mathrm{ET} / \mathrm{ET}_{\mathrm{eq}}$ & $0.70^{*}$ & $0.51^{*}$ & $0.47^{*}$ & 0.69 & 0.92 & 0.76 & 0.79 & 0.77 & 0.73 & 0.70 & 0.84 & 0.85 & 0.73 & 0.13 \\
\hline ET floor (mm) & & & & & & & & 70 & 76 & 75 & 73 & 56 & 70 & 8.15 \\
\hline ET floor/ET & & & & & & & & 0.23 & 0.25 & 0.23 & 0.21 & 0.16 & 0.23 & 0.03 \\
\hline $\begin{array}{l}H \text { floor } \\
\left(\mathrm{MJ} \mathrm{m}^{-2} \mathrm{a}^{-1}\right)\end{array}$ & & & & & & & & 153 & 161 & 170 & 180 & 191 & 171 & 13 \\
\hline$H$ floor $/ H$ & & & & & & & & 0.33 & 0.27 & 0.23 & 0.35 & 0.48 & 0.33 & 0.10 \\
\hline$T_{\mathrm{a}}\left({ }^{\circ} \mathrm{C}\right)$ & 4.3 & 3.4 & 4.3 & 5.3 & 3.9 & 4.2 & 4.1 & 4.1 & 4.6 & 4.9 & 4.8 & 5.0 & 4.4 & 0.5 \\
\hline$T_{\mathrm{S}}\left({ }^{\circ} \mathrm{C}\right)$ & 4.7 & 4.6 & 5.0 & 5.7 & 5.3 & 4.9 & 4.7 & 4.6 & 5.2 & 5.1 & 5.3 & 5.2 & 5.0 & 0.3 \\
\hline$D(\mathrm{kPa})$ & 0.27 & 0.18 & 0.26 & 0.22 & 0.25 & 0.34 & 0.27 & 0.29 & 0.31 & 0.38 & 0.31 & 0.28 & 0.28 & 0.05 \\
\hline$U\left(\mathrm{~m} \mathrm{~s}^{-1}\right)$ & 3.7 & 3.7 & 3.6 & 3.8 & 3.5 & 3.4 & 3.6 & 3.3 & 3.5 & 3.6 & 3.5 & 3.4 & 3.55 & 0.12 \\
\hline
\end{tabular}

Table 2. As Table 1 but for July-August: $R_{\mathrm{g}}$ and $R_{\mathrm{n}}$ are global and net radiation, $H, \mathrm{LE}$ and $G$ sensible, latent and soil heat fluxes, Precip and ET accumulated precipitation and evapotranspiration, $\mathrm{ET}_{\mathrm{eq}}$ the equilibrium evaporation (Eq. 6), $\beta$ Bowen ratio (H/LE), $\Omega$ de-coupling coefficient (Eq. 5), $g_{\mathrm{s}}$ surface conductance, $T_{\mathrm{a}}$ and $T_{\mathrm{S}}$ air and soil temperatures, $D$ vapor pressure deficit, $\theta$ volumetric soil moisture content at 5-25 cm depth and $U$ mean wind speed. $g_{\mathrm{s}}$ and $\Omega$ correspond to daytime (08:00-20:00) conditions. Values marked with $*$ should be interpreted with care because the LE values in 1997-1999 are likely to be underestimates.

\begin{tabular}{|c|c|c|c|c|c|c|c|c|c|c|c|c|c|c|}
\hline & 1997 & 1998 & 1999 & 2000 & 2001 & 2002 & 2003 & 2004 & 2005 & 2006 & 2007 & 2008 & mean & std \\
\hline$R_{\mathrm{g}}\left(\mathrm{MJ} \mathrm{m}^{-2} \mathrm{~d}^{-1}\right)$ & 17.3 & 14.1 & 16.9 & 15.0 & 16.9 & 17.6 & 15.1 & 13.2 & 14.7 & 19.8 & 16.2 & 13.1 & 15.8 & 2.0 \\
\hline$R_{\mathrm{n}}\left(\mathrm{MJ} \mathrm{m}^{-2} \mathrm{~d}^{-1}\right)$ & 10.5 & 11.0 & 10.0 & 9.0 & 10.2 & 10.8 & 10.4 & 8.7 & 9.7 & 11.8 & 9.5 & 9.0 & 10.0 & 0.9 \\
\hline$H\left(\mathrm{MJ} \mathrm{m}^{-2} \mathrm{~d}^{-1}\right)$ & 3.4 & 2.4 & 3.5 & 2.9 & 2.7 & 3.4 & 3.0 & 2.3 & 2.5 & 5.8 & 2.7 & 2.0 & 3.1 & 1.0 \\
\hline $\mathrm{LE}\left(\mathrm{MJ} \mathrm{m}^{-2} \mathrm{~d}^{-1}\right)$ & $5.9^{*}$ & $3.7^{*}$ & $3.6^{*}$ & 5.0 & 6.8 & 5.7 & 5.8 & 4.7 & 4.5 & 4.8 & 5.5 & 4.8 & 5.1 & 0.9 \\
\hline$G\left(\mathrm{MJ} \mathrm{m}^{-2} \mathrm{~d}^{-1}\right)$ & & & & & & & & & 0.69 & 0.60 & 0.63 & 0.53 & 0.61 & 0.07 \\
\hline Precip (mm) & 186 & 226 & 140 & 194 & 130 & 137 & 140 & 182 & 236 & 107 & 194 & 256 & 153 & 54 \\
\hline$\beta$ & $0.58^{*}$ & $0.63^{*}$ & $0.98^{*}$ & 0.57 & 0.40 & 0.59 & 0.52 & 0.50 & 0.56 & 1.21 & 0.49 & 0.43 & 0.62 & 0.24 \\
\hline ET (mm) & $149^{*}$ & $94^{*}$ & $92^{*}$ & 128 & 172 & 145 & 147 & 118 & 115 & 122 & 139 & 121 & 129 & 23 \\
\hline $\mathrm{ET}_{\mathrm{eq}}(\mathrm{mm})$ & 181 & 177 & 167 & 148 & 173 & 185 & 178 & 144 & 155 & 196 & 150 & 140 & 166 & 18 \\
\hline$\alpha=\mathrm{ET} / \mathrm{ET}_{\mathrm{eq}}$ & $0.82^{*}$ & $0.53^{*}$ & $0.55^{*}$ & 0.86 & 0.99 & 0.79 & 0.82 & 0.82 & 0.74 & 0.62 & 0.93 & 0.87 & 0.78 & 0.14 \\
\hline ET/Precip & $0.82^{*}$ & $0.35^{*}$ & $0.66^{*}$ & 0.66 & 1.32 & 1.06 & 1.05 & 0.65 & 0.49 & 1.14 & 0.72 & 0.47 & 0.70 & 0.30 \\
\hline$\Omega$ & $0.40^{*}$ & $0.37^{*}$ & $0.25^{*}$ & 0.43 & 0.37 & 0.31 & 0.36 & 0.31 & 0.26 & 0.19 & 0.31 & 0.30 & 0.32 & 0.07 \\
\hline$g_{\mathrm{s}}\left(\mathrm{mm} \mathrm{s}^{-1}\right)$ & $6.5^{*}$ & $8.2^{*}$ & $5.0^{*}$ & 13.1 & 8.5 & 5.8 & 9.6 & 6.3 & 4.8 & 3.5 & 7.2 & 6.4 & 7.1 & 2.5 \\
\hline$T_{\mathrm{a}}\left({ }^{\circ} \mathrm{C}\right)$ & 17.4 & 13.7 & 14.9 & 14.5 & 16.4 & 17.5 & 17.1 & 15.1 & 16.2 & 17.6 & 15.6 & 13.8 & 15.80 & 1.42 \\
\hline$T_{\mathrm{S}}\left({ }^{\circ} \mathrm{C}\right)$ & 13.2 & 11.5 & 11.7 & 12.1 & 12.7 & 13.6 & 13.2 & 11.4 & 12.5 & 12.6 & 12.7 & 11.6 & 12.39 & 0.75 \\
\hline$D(\mathrm{kPa})$ & 0.65 & 0.31 & 0.57 & 0.36 & 0.60 & 0.79 & 0.55 & 0.58 & 0.68 & 0.96 & 0.58 & 0.50 & 0.59 & 0.17 \\
\hline$\theta\left(\mathrm{m}^{3} \mathrm{~m}^{-3}\right)$ & 0.30 & 0.43 & 0.18 & 0.24 & 0.23 & 0.24 & 0.22 & 0.41 & 0.29 & 0.15 & 0.27 & 0.34 & 0.28 & 0.08 \\
\hline$U\left(\mathrm{~m} \mathrm{~s}^{-1}\right)$ & 3.0 & 3.2 & 3.4 & 3.2 & 3.5 & 3.1 & 3.1 & 3.2 & 3.2 & 3.3 & 3.1 & 3.3 & 3.2 & 0.2 \\
\hline
\end{tabular}



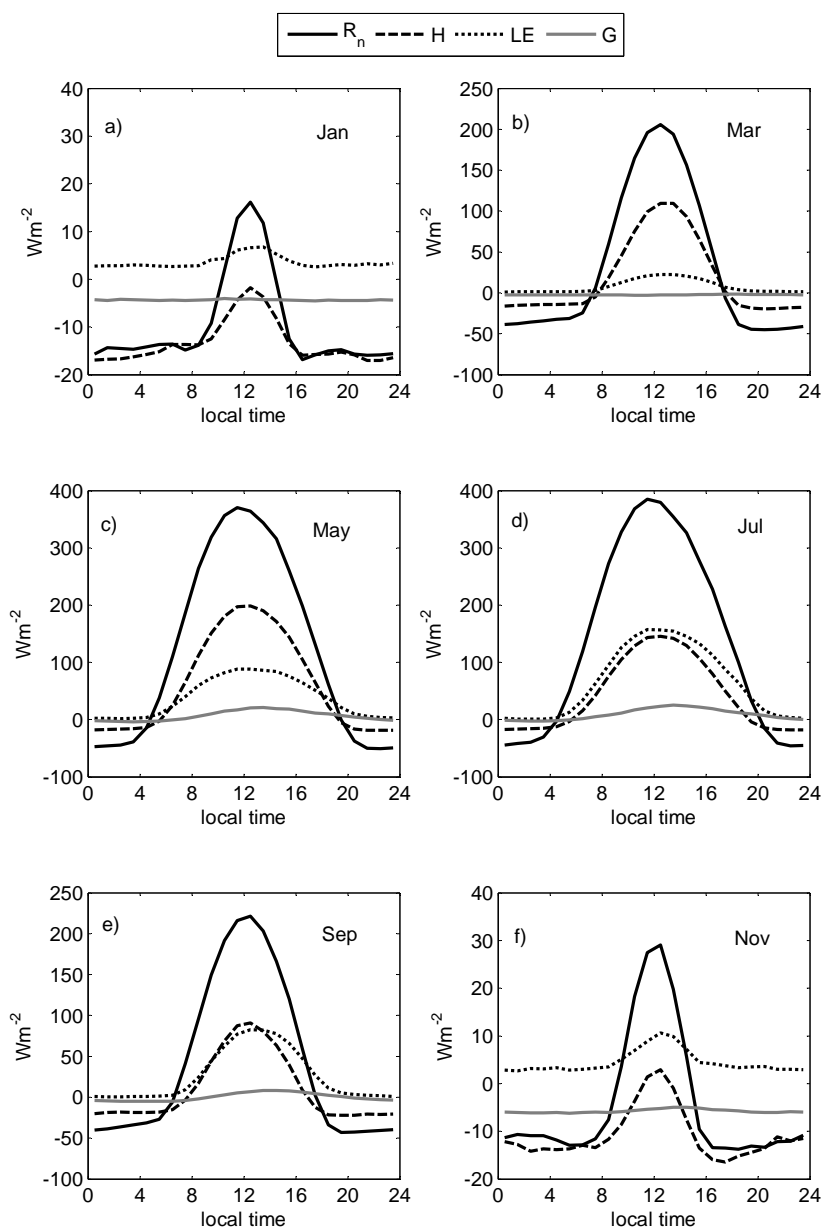

Fig. 4. Diurnal cycles of the main energy balance components on monthly basis during a typical year (2007). Net radiation $\left(R_{\mathrm{n}}\right)$, sensible $(H)$ and latent heat fluxes (LE) and soil heat flux $(G)$. Note varying y-axis between sub-figures.

nighttime $H$ is around $-20 \mathrm{~W} \mathrm{~m}^{-2}$ with extremes reaching below $-100 \mathrm{~W} \mathrm{~m}^{-2}$ in clear stable nights (not shown). LE remains very low, less than $10 \mathrm{~W} \mathrm{~m}^{-2}$. The snow-covered soil is cooling but the magnitude of $G$ remains small under the insulating snow cover. Because of low radiation levels and small number of sunlight hours the diurnal amplitudes of all energy balance components are small (Fig. 4a, f) and the daytime peak narrow. In March-April the energy fluxes start to rise rapidly and the diurnal amplitude increase. $R_{\mathrm{n}}$ is consumed mainly to $H$, which has a typical daytime peak around $+100 \mathrm{~W} \mathrm{~m}^{-2}$ while LE remains low $\left(<30 \mathrm{~W} \mathrm{~m}^{-2}\right)$. When spring progresses, the evapotranspiration enhances both in absolute sense and compared to $H$; Bowen ratio ( $\beta$, Fig. 6a) decreases rapidly from the range 410 observed in late March to between 2 and 3 in May. The ground heat flux turns positive (downward) immediately after snowmelt and soil starts to warm.

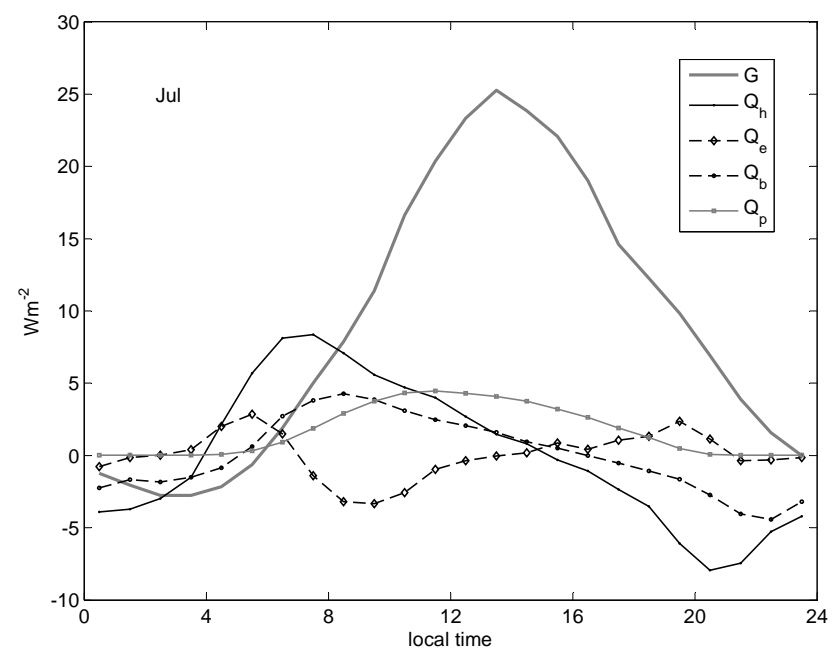

Fig. 5. Diurnal cycle of storage terms in July 2007: sensible heat $\left(Q_{\mathrm{h}}\right)$, latent heat $\left(Q_{\mathrm{e}}\right)$ and biomass $\left(Q_{\mathrm{b}}\right)$ storage fluxes. and energy consumed in photosyhthesis $\left(Q_{\mathrm{p}}\right)$. The ground heat flux $(G)$ is given for for reference. Note that storage terms are largest in June-August but still remain order of magnitude smaller than $R_{\mathrm{n}}$ and turbulent fluxes shown in Fig. 4.
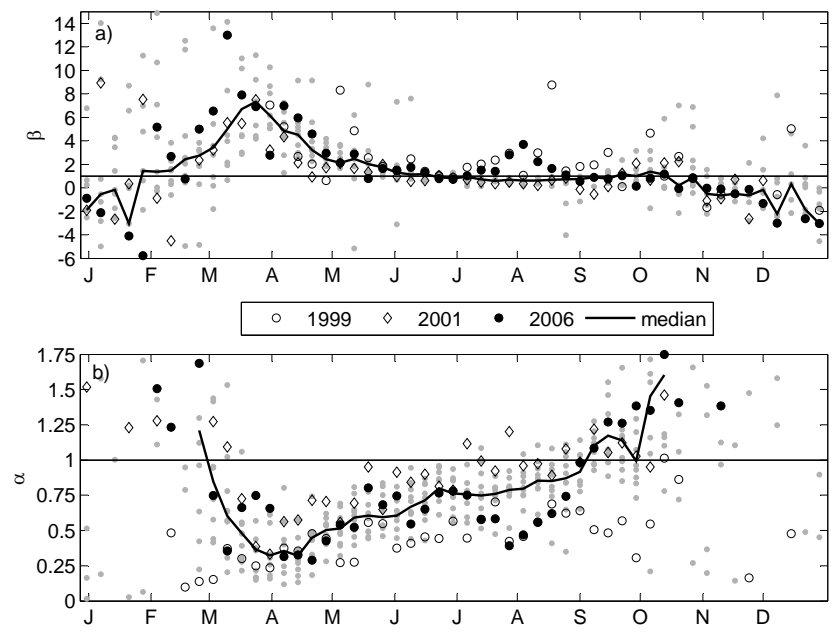

Fig. 6. Seasonal and inter-annual variability of (a) Bowen ratio $(\beta)$ and (b) Priestley-Taylor $\alpha=\mathrm{LE} / \mathrm{LE}_{\mathrm{eq}}$. The points represent weekly averages and the thick solid line the median over 1997-2008. The $\beta$ is weighted by global radiation and hence represents the daytime conditions while $\alpha$ is calculated from weekly sums. In NovemberFebruary the median is not shown because of large variability of $\beta$ and $\alpha$.

The seasonal peak in $H$ is normally in May-June (monthly mean $\approx 60-70 \mathrm{~W} \mathrm{~m}^{-2}, 5-6 \mathrm{MJ} \mathrm{m}^{-2} \mathrm{~d}^{-1}$, typical daytime peak around $+200 \mathrm{~W} \mathrm{~m}^{-2}$ with maximum values exceeding $+500 \mathrm{~W} \mathrm{~m}^{-2}$ ) and thereafter it either plateaus or starts gradually to decline. Seasonal course of LE lags $H$ by $1.5-2$ months peaking in July-August: monthly mean $40-75 \mathrm{~W} \mathrm{~m}^{-2}$ (corresponds to $1.5-2.8 \mathrm{~mm}$ of ET) 
and typical diurnal maximum $170 \mathrm{~W} \mathrm{~m}^{-2}$ with extremes in $350-400 \mathrm{~W} \mathrm{~m}^{-2}$. Consequently, during "average" summers, daytime $\beta$ (Fig. 6a) reaches its growing season minimum in late July-early August ranging from 0.3-0.4 (2001) to 0.8 (2007). The intra-annual peak in $G$ appears in June-July (30-day mean $\approx 11 \mathrm{~W} \mathrm{~m}^{-2}$, equals $0.9 \mathrm{MJ} \mathrm{m}^{-2} \mathrm{~d}^{-1}$ ), in phase with the maximum in $R_{\mathrm{n}}$ (Fig. 3). On diurnal scale, the peak in $G$ lags $R_{\mathrm{n}}$ by $\approx 2-3 \mathrm{~h}$ (Fig. 4 ). The monthly mean $R_{\mathrm{n}}$ reach the zero level in late October when daily average $R_{\mathrm{g}}$ has dropped around $50 \mathrm{~W} \mathrm{~m}^{-2}$. The sensible and latent heat fluxes decrease with the diminishing $R_{\mathrm{n}}$ as expected and the drop is more dramatic in LE that peaked later in the summer. Thus, the daytime $\beta$ increases slightly over unity late September-early October (Fig. 6a). The ground heat flux turns negative in September-October depending on the year.

The strong seasonal change in the relative importance of $H$ and LE is evident from Figs. 3-6. The studied pine forest is in strongly sensible heat dominated phase in spring (March-May) but the importance of ET increases monotonically during the summer and the ecosystem reaches evapotranspiration dominated phase in late summer (JulyAugust). To consider the diurnal variability, each of the $R_{\mathrm{n}}, G$ and the storage fluxes are comparable between May and July but the average diurnal maximum LE increases from $\approx 100 \mathrm{~W} \mathrm{~m}^{-2}$ to $180 \mathrm{~W} \mathrm{~m}^{-2}$ while $H$ decreases from $+200 \mathrm{~W} \mathrm{~m}^{-2}$ to $+140 \mathrm{~W} \mathrm{~m}^{-2}$. Same change in $\beta$ can be seen between March and September, again months with comparable $R_{\mathrm{n}}$ (Fig. 4). In autumn, the magnitude of the energy fluxes and their diurnal variability decreases and the variability between the different years is comparable to the spring. The storage fluxes $\left(Q_{\mathrm{h}}, Q_{\mathrm{e}}\right.$ and $\left.Q_{\mathrm{b}}\right)$ are largest during the transition periods around sunrise and sunset while also their relative importance in the energy budget is at its highest (Fig. 5). $Q_{\mathrm{p}}$ peaks in June-August when $\mathrm{CO}_{2}$ uptake is strongest but remains below $5 \mathrm{~W} \mathrm{~m}^{-2}$ on average. In short, the storage terms are order of magnitude smaller than $R_{\mathrm{n}}$ and turbulent fluxes in this well-ventilated forest ecosystem.

\subsection{Seasonality of "big-leaf" surface conductance and influence on energy partitioning}

Figure $6 \mathrm{~b}$ shows the seasonal course of the ratio of actual to equilibrium evaporation ( $\alpha=\mathrm{LE} / \mathrm{LE}_{\mathrm{eq}}$, Priestley and Taylor, 1972) calculated from weekly accumulated evapotranspiration. In wintertime and in autumn $\alpha$ is highly variable, most likely because both the measured LE and available energy are small and hence the large relative uncertainty may cause irregular variability when $\alpha$ is evaluated from the measurements. In March-April the actual evapotranspiration accounts typically only from $10 \%$ to $40 \%$ of atmospheric demand although the snow is melting during these months. The springtime depression in $\alpha$ occurs concurrently with the spring peak in $\beta$ (Fig. 6a). After that, $\alpha$ increases and reaches the typical growing season value $(0.7-0.9)$ in late June-early July when the conditions are most favorable with plentiful
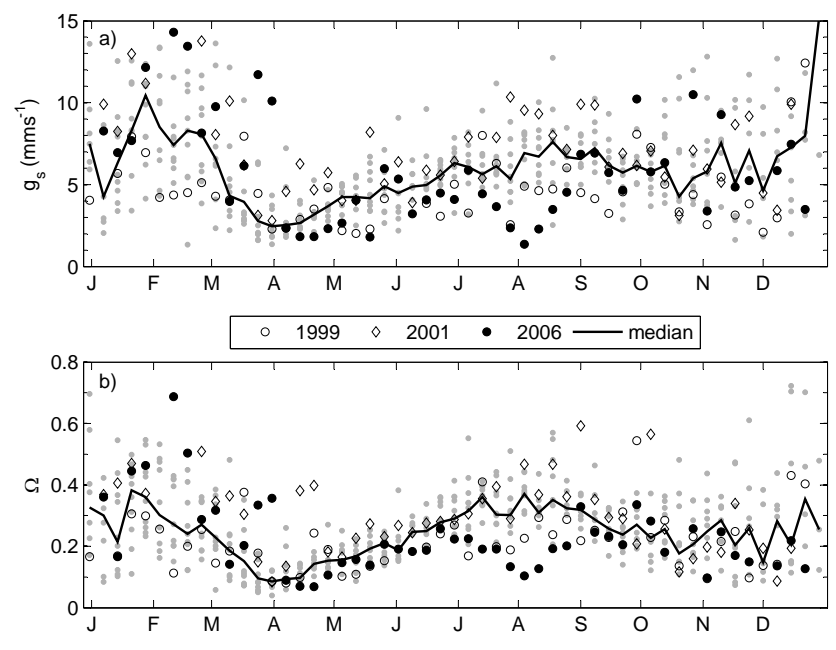

Fig. 7. Seasonal and inter-annual variability of (a) surface conductance $\left(g_{\mathrm{s}}, \mathrm{mm} \mathrm{s}^{-1}\right)$ and (b) de-coupling coefficient $(\Omega)$. The points represent weekly averages on daytime (08:00-20:00) and the solid line the weekly median over 1997-2008. Wet canopy conditions are discarded.

extractable water, high radiation and suitable temperature (Fig. 2). Usually, $\alpha$ remains at this level until late August and increases in September-October.

Figure 7 illustrates the physiological control of the evapotranspiration through the mean daytime (08:00-20:00) $g_{\mathrm{s}}$ and $\Omega$. Although a notable scatter in wintertime, there is a distinct seasonal cycle in $g_{\mathrm{s}}$ having a minimum in late Marchearly April, around $2-3 \mathrm{~mm} \mathrm{~s}^{-1}$, followed by an increase reaching 5-7 $\mathrm{mm} \mathrm{s}^{-1}$ in late June (Fig. 6a). Later in summer, $g_{\mathrm{s}}$ depends on the climatic conditions: years with low $D$ and ample $\theta$ (such as 2001) are characterized by high $g_{\mathrm{s}}(8-$ $10 \mathrm{~mm} \mathrm{~s}^{-1}$ in July-early August). On the other hand, when water availability is restricted and $D$ remains high (1999, 2006) $g_{\text {s }}$ can stay as low as $2 \mathrm{~mm} \mathrm{~s}^{-1}$ (in late July 2006). Autumn and winter $g_{\mathrm{s}}$ behaves unstably because the fluxes are small and relative errors become significant when inverting $g_{\mathrm{s}}$ from EC data. However, large $g_{\mathrm{s}}$ is consistent with the increased importance of surface evaporation, which is not controlled by the stomatal action but driven by the available energy and downward $H$.

Because of the seasonality of surface conductance, also de-coupling coefficient has a distinct intra-annual variability: a minimum in March-April (0.05-0.1), increase thereafter $(\approx 0.2$ in May) and a peak in June $(0.25-0.35)$. In late summer and early autumn $\Omega$ drops, in line with the decreasing $g_{\mathrm{s}}$ and increasing $\beta$. The $\Omega$ confirms that $n$ dry-canopy conditions energy partitioning is strongly controlled by the vegetation through stomatal regulation. Moreover, the biological control is stronger (stomatal conductance smaller) in spring and the degree of coupling to $R_{\mathrm{a}}$ increases towards the summer. The years 2001 (moist growing season) and 2006 (extremely dry) were the two extremes in terms of $\Omega$ but IAV 

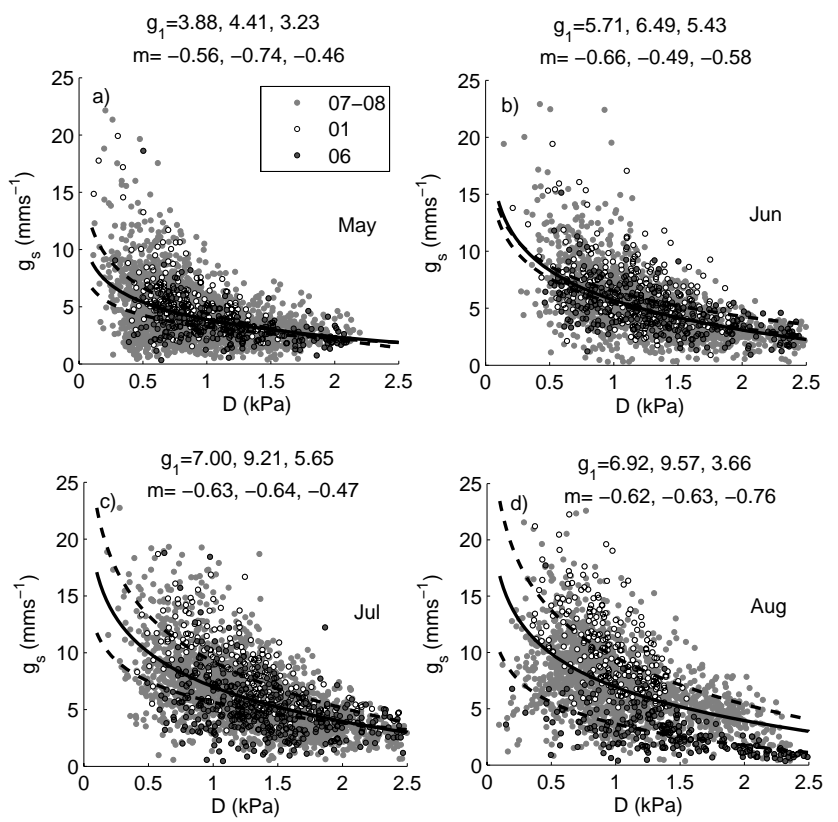

Fig. 8. Sensitivity of surface conductance $\left(g_{\mathrm{s}}\right)$ to vapor pressure deficit $(D)$ during May (a), June (b), July (c) and August (d). The model fitted to data is $g_{\mathrm{s}}=g_{1}-m \times \ln (D)$ according to Oren et al. (1999) where $g_{1}$ represents conductance at $1 \mathrm{kPa}$ and $m$ is the sensitivity to $D$. The parameters $g_{1}$ and $m$ are given for each month and years 2007-2008, 2001 and 2006, respectively.

of $\Omega$ is smaller than intra-annual (Fig. 7). Similarly to $g_{\mathrm{s}}, \Omega$ varied most in July-August when the range of environmental conditions $\left(R_{\mathrm{g}}, D, \theta\right)$ was the broadest. The drought stress as observed in July-August 2006 and 1999 stimulated gradual stomatal closure, manifested by decrease in $g_{\mathrm{s}}$ and transpiration. Simultaneously $\alpha$ and $\Omega$ drop and $\beta$ increased to 3-4 compared to typical value $0.6-0.8$ (Figs. 3, 6 and 7).

Oren et al. (1999) described the response of stomata to vapor pressure deficit (at leaf-scale) using an equation $g_{\mathrm{s}}=$ $g_{\text {sref }}-m \times \ln (D)$, where $g_{\text {sref }}$ is the conductance at $1 \mathrm{kPa}$ and $m$ is the stomatal sensitivity. They showed that $g_{\text {sref }}$ and $m$ are highly correlated and large number of species cluster along a slope $m / g_{\text {sref }} \approx 0.6$ that was shown to be consistent with a hydrological model that assumes the stomatal regulation of leaf water potential. In the "big-leaf" framework, $g_{\mathrm{s}}$ represents the integral of each single stoma (and soil evaporation) in the canopy space and thus provide an aggregated measure of the stomatal sensitivity. Figure 8 shows the sensitivity of $g_{\mathrm{s}}$ to $D$ in abundant light (PAR $>600 \mu \mathrm{mol} \mathrm{m}{ }^{-2} \mathrm{~s}^{-1}$ ) for several growing season months and years. It appears that $m / G_{\text {sref }}$ is rather stable $[-0.48 ;-0.59]$ but $g_{\text {sref }}$ varies by a factor of two over the season having a minimum $\left(\approx 2.5-3.5 \mathrm{~mm} \mathrm{~s}^{-1}\right)$ in spring and maximum in July August $\left(\approx 7 \mathrm{~mm} \mathrm{~s}^{-1}\right)$. The stomatal sensitivity during the wet and dry summers 2001 and 2006 indicate that in wet conditions $g_{\text {sref }}$ is markedly higher than during drought-

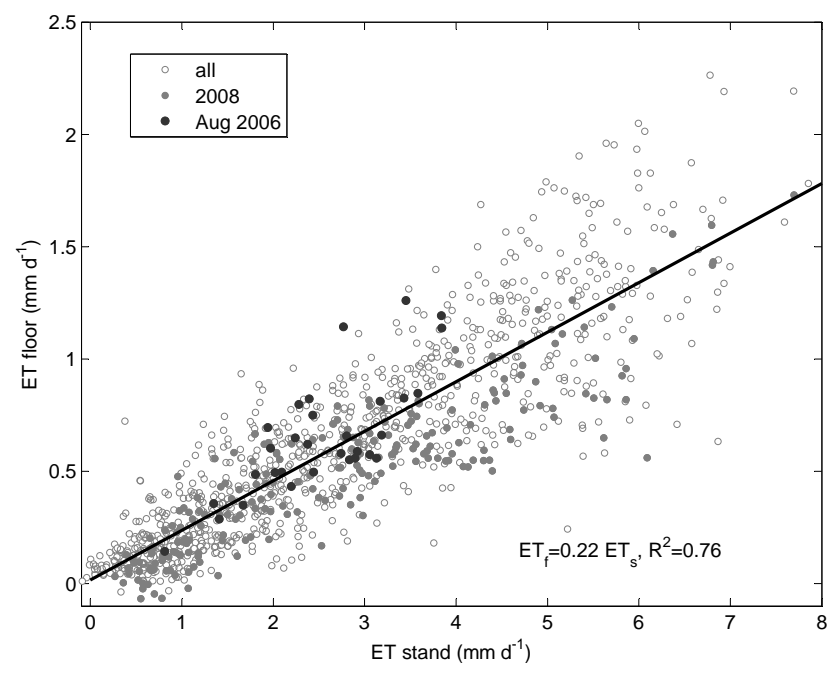

Fig. 9. Daily forest floor evapotranspiration versus whole stand ET for April to October period (2003-2008). In year 2008 ET floor was $18 \%$ of stand ET, lower than average $22 \%$ shown as linear fit. The drought in August 2006 did not markedly alter the ET partitioning.

stressed conditions as in August 2006. In addition, $\mathrm{m} / \mathrm{g}_{\text {sref }}$ remains more stable over range of microclimatic conditions than $g_{\text {sref. }}$. Based on Fig. 8 and similar analysis of shoot scale gas-exchange measurements (not shown), it can be hypothesized that the stomatal sensitivity to $D$ is rather constant but the "maximum aperture of the stomata" (here expressed in terms of $g_{\text {sref }}$ ) increases along the seasonal cycle of physiological activity.

\subsection{Canopy and forest floor components}

In 2004-2008 the forest floor energy exchange was measured by a sub-canopy EC unit similar to that above the canopy (Launiainen et al., 2005). The energy balance closure of 0.86 was found on daily timescale in summer 2005 when $R_{\mathrm{n}}$ at forest floor was measured by five sensors (not shown). Comparison of trunk-space (at $3.5 \mathrm{~m}$ height) and above-canopy EC measurements during 2004-2008 indicated that on the annual timescale, the forest floor evapotranspiration was between 22 and $25 \%$ (equals to $70-76 \mathrm{~mm}$ ) of stand ET in all years except in 2008 when the contribution was $18 \%(56 \mathrm{~mm})$. The scatter plot of daily forest floor against stand ET during April-October period (Fig. 9) indicates a strong linear relationship between the two. The forest floor contribution to total ET was constant over wide range of environmental conditions, whose changes well explained the variability along the linear relationship (fitted line) but not the scatter around it. Moreover, the drought period in August 2006 did not differ notably from other periods, which indicate that the forest floor ET (primarily transpiration in these conditions) was reduced by same manner than the pine transpiration. The forest floor contribution 
peaked in spring $(\approx 0.25-0.3)$ and decreased slightly towards the autumn $(\approx 0.15-0.2$, not shown). In years with early snowmelt, such as 2007, the forest floor contribution was around $0.4-0.5$ during the first 2-3 weeks after the snowmelt. It is likely that surface evaporation from the wet soil and mosses was significant while the slow recovery of photosynthetic capacity and water and solute transport in the pines restricted transpiration rates, as discussed later.

The sensible heat flux in trunk-space contributed around 10 to $20 \%$ of ecosystem scale $H$ during the growing season; the contribution was largest in spring and decreased thereafter. In short, over the snow-free season the dynamics of forest floor $H$ and LE were quite similar to the whole forest fluxes. At maximum, forest floor LE reached 80$100 \mathrm{~W} \mathrm{~m}^{-2}$ and $H 100-130 \mathrm{~W} \mathrm{~m}^{-2}$. During the snowmelt period in spring the temperature at the snow covered forest floor remains constant $\left(0^{\circ} \mathrm{C}\right)$ while the absorbed radiation heats the canopy leading to strong upward $H$ above the canopy $\left(+200 \mathrm{~W} \mathrm{~m}^{-2}\right)$ and downward (between -30 and $-20 \mathrm{~W} \mathrm{~m}^{-2}$ ) in trunk-space. Thus, the energy absorbed by the foliage provides indirectly energy for snowmelt. During this period sublimation rates from the snow remain very small, less than $20 \mathrm{~W} \mathrm{~m}^{-2}$, and hence only minor fraction of the water stored as snow evaporates directly to atmosphere but instead provides moisture input to the soil. However, immediately after the snow has melted, the forest floor LE and $H$ increase markedly as does $G$. During nights and in wintertime the sensible heat transport from the forest floor is close to zero.

\subsection{Annual balances and variability}

The annually accumulated energy fluxes and annual climate characteristics are represented in detail in Table 1. On an annual timescale the studied Scots pine forest received between 2783 and $3453 \mathrm{MJ} \mathrm{m}^{-2}$ (mean $3141 \mathrm{MJ} \mathrm{m}^{-2} \mathrm{a}^{-1}$ ) of solar radiation of which between 47 to $60 \%$ was available for energy exchange in form of net radiation. The $R_{\mathrm{n}} / R_{\mathrm{g}}$ ratio was smallest in 2007 and greatest in 1999 and 2008. $R_{\mathrm{n}}$ was partitioned mainly into latent and sensible heat that accounted between $42-57 \%$ and $29-41 \%$ on annual basis. Thus, $\beta$ calculated from annual balances was between 0.47 (2008) and 0.93-0.94 (2006, 2000). The ET accumulated over the summer was independent of the amount of precipitation. The annual evapotranspiration was conservative and rather stable (283-361 mm, years 1997-1999 excluded). The annual ratio between actual and equilibrium ET varied between 0.69 and 0.92 (0.78 (mean) \pm 0.07 (std) over 2000-2008).

Both energy exchange and its variability are greatest in summer months when $R_{\mathrm{g}}$ is high: $61-74 \%$ of the annually received shortwave radiation is accumulated and between 66 and $79 \%$ of annual ET takes place during May-August period. The effect of environmental conditions on IAV over this period was assessed using multi-linear regression analysis. The variables were entered and/or removed stepwise to the regression equation based on F-statistics significance level of 0.05 and 0.10 . Tested explaining variables were total and diffuse global radiation, $T_{\mathrm{a}}, T_{\mathrm{s}}, D, \theta$, precipitation and wind speed. The four-month average incoming global radiation explained 58 and $79 \%$ of the IAV of $R_{\mathrm{n}}$ and $H$, respectively, and all the studied years collapsed well along the linear relationship (Fig. 10). The LE (or ET) variability was independent on $R_{\mathrm{g}}$ and instead best explained by $T_{\mathrm{S}}$ $\left(R^{2}=0.32, p>0.05\right)$, presumably because soil temperature comprises both the effect of radiation and soil moisture, but the relationship was statistically insignificant. On the contrary to $H$, measured LE did not scale similarly 1997-1999, which had significantly poorer energy balance closure, and 2000-2008. As no other causes were found it is likely that the poor EBC during the pioneering years was primarily because of underestimated evapotranspiration. Therefore, the causes of IAV of $g_{\mathrm{s}}$ and $\Omega$ were evaluated based on 20002008 data only. $D$ explained $69 \%(p<0.05)$ of the IAV of $g_{\mathrm{s}}$ while the best explaining factors of $\Omega$ were $D(57 \%$, $p<0.05$ ), and $D$ and $T_{\mathrm{S}}$ (total $79 \%, p<0.05$ ). Thus, the found factors behind IAV were physically and physiologically defendable and proportion of explained variance rather high. On an annual timescale a significant relationship was found only for $H$ which variability was partly explained by global radiation $\left(R^{2}=0.48, p<0.05\right)$.

\section{Discussion}

\subsection{Energy balance closure}

The surface energy balance could not be closed by the micrometeorological measurements either at short-term $(1 / 2 \mathrm{~h})$ or annual scale. The energy balance closure (EBC) evaluated as a slope of the linear regression between available energy and turbulent fluxes over May-October period ranged from 0.83 to 0.95 for 2000 to 2008 period while the closure was poorer during the first three years $(0.66$ in 1999). The found values resemble the typical range measured over terrestrial ecosystems, forests in particular (Wilson et al., 2002b; Barr et al., 2006; Grünwald and Bernhofer, 2007; Foken, 2008; Moderow et al., 2009). The mismatch between available energy and turbulent fluxes may originate from various reasons, including measurement inaccuracies, incomplete estimation of the storage terms, un-representativeness of EC flux footprint compared to net radiation measurements etc. However, in a recent review by Foken (2008) these "classical" explanations for unclosed energy balance were suggested to be of secondary importance compared to larger-scale processes. Foken (2008) brought up the importance of the contribution of large eddies on surface atmosphere exchange and hypothesized the energy balance to be closed only at landscapescale, not at the scale measured by micrometeorological methods. Although a detailed scrutiny of the reasons of unclosed energy balance is beyond the scope of this paper, a few 

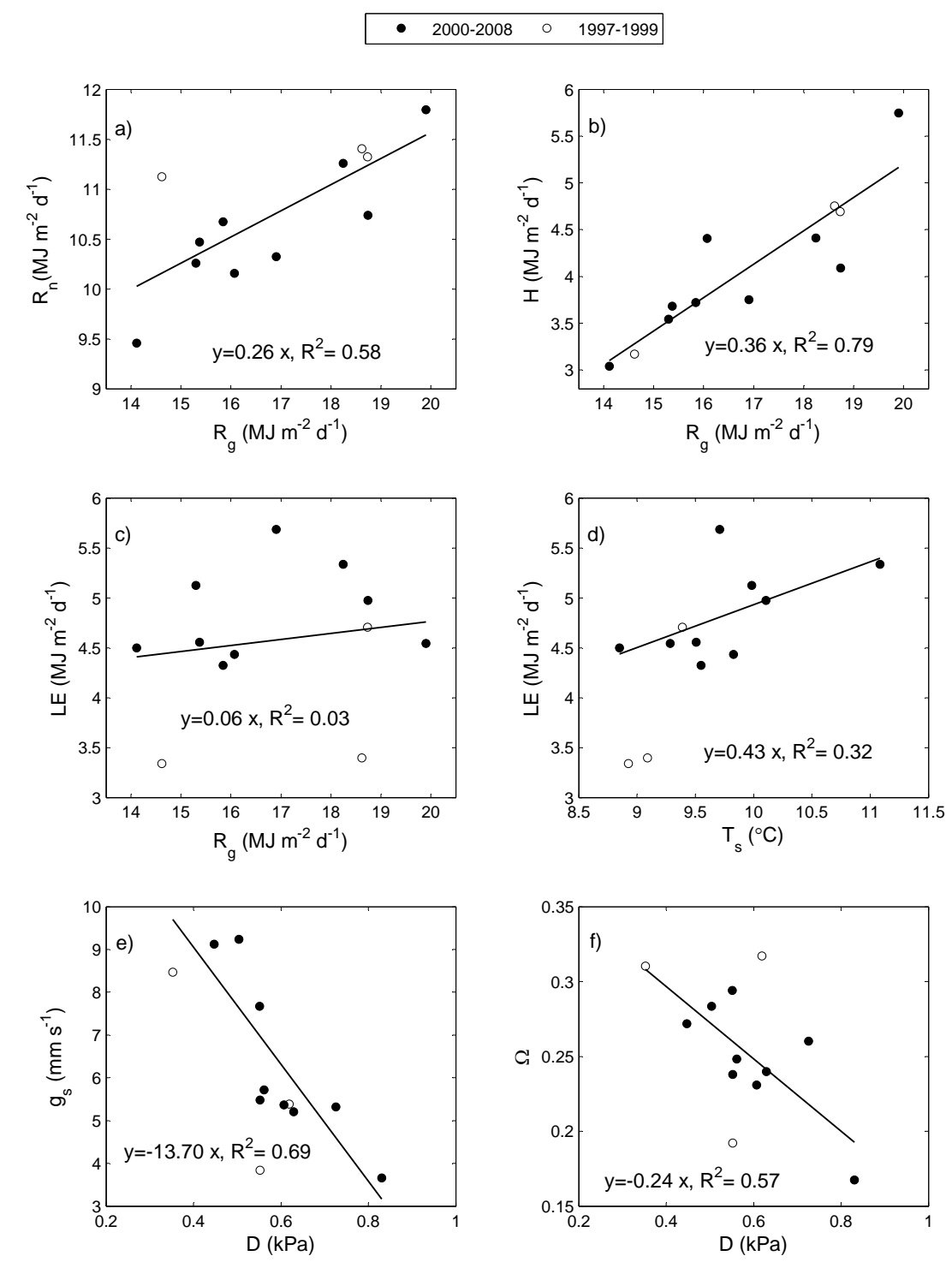

Fig. 10. Mean summertime (May-August) (a) net radiation $\left(R_{\mathrm{n}}\right)$, (b) sensible heat flux $(H)$, (c)-(d) latent heat flux (LE) and (e) daytime (08:00-20:00) surface conductance $\left(g_{\mathrm{S}}\right)$ and (f) daytime de-coupling coefficient $(\Omega)$ regressed along their best explaining environmental variable. $R_{\mathrm{g}}, T_{\mathrm{S}}$ and $D$ are four-month mean global radiation, soil temperature and vapor pressure deficit, respectively. The three first years (1997-1999) characterized by poorer energy balance closure are shown with open symbols. The linear least squares regressions are for years 2000-2008 except in panels (a) and (b) where all years are included. Only regression slopes are shown. $R^{2}$ indicates the proportion of explained variance.

findings merit discussion: first, the poor closure during the snow melt period (March-April) is expected since the snow processes and energy storage into snowpack were not taken into account. In late April and in May, however, the EBC was still on average significantly smaller than during JulyAugust (Fig. 1), which could be a fingerprint of the large eddies that are likely to form in the deep convective boundary layer existing over the boreal forests in spring. Consequently, the large eddies may cause the low-frequency transport to gain in importance and $1 / 2 \mathrm{~h}$ averaging period may underestimate the fluxes. In 2001, that had the best annual closure, the April-June period was characterized by cloudy conditions, low $H$ and hence shallow $\mathrm{ABL}$ - and significantly better EBC (Figs. 1-3). Also Lindroth et al. (2010) found that energy balance residual (both normalized and absolute) increased in strongly unstable conditions above a mixed coniferous forest in Sweden. Second, the energy balance closure was on average better later in the summer when $\beta$ was less than unity and large fraction of energy was used in ET. Thus, underestimation of latent heat flux cannot be the main reason for energy balance deficit for years 2000-2008. Third, the storage fluxes were small but had still a minor effect on 
EBC: the annual closure fraction evaluated from $1 / 2 \mathrm{~h}$ fluxes decreased between 3 and 4 percentage units (intercept worsened by order of $1-2 \mathrm{~W} \mathrm{~m}^{-2}$ ) when the storage terms were excluded. Fourth, the markedly poorer EBC in 1997-1999 compared to later years is likely due to underestimated LE, as indicated by the different scaling of LE (contrary to $H$ ) with environmental parameters in Fig. 10. Therefore the latent heat flux data in 1997-1999 should be interpreted with care. Fifth, the IAV of EBC (over May-August) could not be explained by environmental conditions.

\subsection{Annual cycle of photosynthetic activity and its influence on energy flux partitioning}

The low transpiration rates during the springtime and strong canopy-to-air temperature gradient evoke a large fraction of available energy to be partitioned into sensible heat. Gradually, $g_{\mathrm{s}}$ and evapotranspiration increase, $\beta$ decreases and from mid June to early September LE takes over $H(\beta<1)$. In short, although the annual cycle of energy fluxes is primarily determined by the radiation input, there is strong seasonal variability on energy partitioning: on the seasonal timescale $H$ peaks in May-early June and LE in July-August and this is a mainly caused by the annual cycle of stomatal conductance (Figs. 3 and 7). The observed seasonality in energy partitioning resembles what is found earlier in similar ecosystems. Tchebakova et al. (2002) showed that in early spring, in absence of physiological activity, a large fraction $(\approx 80 \%)$ of available energy is partitioned into sensible heat and thus $\beta$ exceeded 8 in a Siberian Scots pine forest. Within the following weeks, associated to recovery of photosynthetic capacity, the transpiration rates rapidly increased and $\beta$ dropped. Similarly, the ratio of actual to equilibrium evaporation $(\alpha)$ was close to 0.5 shortly after the snowmelt but increased towards the summer and reached values close to one while Bowen ratio decreased well below unity (Arneth et al., 2006).

Coniferous trees in boreal zone have a clear annual cycle of photosynthetic activity; the rate of assimilation is low or zero in the winter, increases during the spring, peaks in JulyAugust followed by a decline in autumn (Pelkonen and Hari, 1980; Bergh and Linder, 1999; Mäkelä et al., 2004; Kolari et al., 2007). Part of the annual cycle can be attributed to instantaneous responses of photosynthetic rate to changes in daily patterns of environmental driving factors such as increase of light levels and temperature in spring and their declining trends in autumn. However, the internal state of the photosynthetic machinery (i.e. state of functional substances such as enzymes) and thus instantaneous responses to environmental drivers vary within the year (Pelkonen and Hari, 1980). Spring recovery of photosynthetic capacity has been attributed to a delayed effect of rising temperatures (Pelkonen and Hari, 1980; Bergh et al., 1998). Mäkelä et al. (2004) found that while the light response curve of Scots pine varied over the season, its shape remained constant (the quantum efficiency remained proportional to light-saturated photosyn- thesis rate) and the seasonal course was efficiently described by a reversible first-order delay process driven by the air temperature, which they defined as "state of acclimation". Recently, Kolari et al. (2007) examined two Scots pine forests in Finland and further demonstrated that the seasonal pattern of photosynthetic efficiency follows the delayed reversible temperature sum model both in southern and northern boreal zones. The delay time constant depends on severity of the winter conditions and length of dormant period and has been found to range from 1 to 2 days in Central Europe $\left(44-50^{\circ} \mathrm{N}\right)$ to about 10 days in Northern Finland $\left(67^{\circ} \mathrm{N}\right)$ (Mäkelä et al., 2008).

The low evapotranspiration rates of boreal coniferous forests in spring have typically been attributed to soil water uptake limitations caused by frozen soil or high viscosity of cold water (Halldin et al., 1980; Teskey et al., 1984; Turnipseed et al., 2002). At the SMEAR II the mineral soil temperatures remained above zero during all winters except 2002-2003. The permanent snow normally falls when the soil temperature still is above zero and the snowpack efficiently isolates the soil from the air. In 2002 the autumn was very dry and cloudless and hence $\theta$ and the heat capacity of the soil were low permitting the soil to freeze before first snowfalls (Fig. 1). Because the soil is seldom frozen and starts to warm rapidly after the snowmelt, the low ET in springtime is primarily caused by the vegetation acclimation process rather than hydraulic limitations and restricted soil water uptake. In autumn, the photosynthesis and thereby transpiration are mainly limited by low levels of solar radiation (Suni et al., 2003; Kolari et al., 2009; Vesala et al., 2009) although night frosts can reduce the photosynthetic capacity and stomatal conductance (Mäkelä et al., 2004; Kolari et al., 2007). Moreover, the effect of seasonal changes in LAI (around 25\%) is likely to be of secondary importance compared to the annual cycle of photosynthetic capacity.

The importance of seasonal acclimation of photosynthetic capacity on forest-atmosphere energy exchange stems from the close coupling of carbon and water cycles in vascular plants. The coupling has lead to development of several theories that link the stomatal regulation to net $\mathrm{CO}_{2}$ exchange $\left(f_{\mathrm{c}}\right)$. The Ball-Berry-model describes $g_{\mathrm{s}}$ as a product of $f_{\mathrm{c}}$ and relative humidity (RH) as (Ball et al., 1987):

$g_{\mathrm{s}}=\frac{m_{1}}{c_{\mathrm{a}}-c_{\mathrm{p}}} f_{\mathrm{c}} \times \mathrm{RH}+g_{0}$,

where $c_{\mathrm{a}}$ is ambient $\mathrm{CO}_{2}$ mixing ratio, $c_{\mathrm{p}} \mathrm{CO}_{2}$ compensation point, $g_{0}$ residual conductance and $m_{1}$ the empirical sensitivity parameter. Alternatively, the function of stoma can be described based on economics of gas-exchange that assumes stomata to operate autonomously to maximize the carbon gains while minimizing water losses (Cowan and Farquhar, 1977; Hari et al., 1986; Katul et al., 2009). The sensitivity of $g_{\mathrm{s}}$ to humidity remained rather constant over the season, especially compared to the value of reference conductance at $D=1 \mathrm{kPa}$ (Fig. 8). The observed values of 
$m / g_{\text {sref }} \approx[-0.48 ;-0.59]$ match exactly the sensitivity range derived using leaf-scale measurements for variety of species in Oren et al. (1999). Moreover, Katul et al. (2009) showed that values of $\mathrm{m} / \mathrm{g}_{\text {sref }}=[-0.5 ;-0.6]$ are consistent with predictions of optimal stomatal control theory. A separate analysis of shoot-scale gas-exchange data indicated (not shown, data published e.g. in Kolari et al., 2007) that the Ball-Berry sensitivity parameter $m_{1}$ remains quite stable throughout the season (5.0 1.0 , average over 2001-2006) and thus the relationship between $g_{\mathrm{s}}$ to the product of $\mathrm{CO}_{2}$ uptake and humidity remains relatively unchanged throughout the year. Also the constancy of humidity response (Fig. 8) suggest that the seasonal course of $g_{\mathrm{s}}$ is resolved if the seasonality of photosynthetic parameters is adequately described as in Mäkelä et al. (2006), Kolari et al. (2007) and Thum et al. (2007).

However, in models and applications where the carbon and water cycles are not coupled, the seasonal course of $g_{\mathrm{s}}$ needs to be accounted separately. Launiainen et al. (2009) used an empirical multiplicative model (Jarvis, 1976), and showed that in early spring a model including modifier functions for $R_{\mathrm{g}}, D$ and state of acclimation described according to Mäkelä et al. (2004) outperformed a model where the latter was replaced by direct response to ambient temperature. This version overestimated midday LE in early April by a factor of two $\left(50-100 \mathrm{~W} \mathrm{~m}^{-2}\right)$ and the fraction can be even greater at more northern latitudes where the recovery from dormancy takes longer. Therefore, impaired description of the seasonal cycle of $g_{\mathrm{s}}$ of boreal conifers can have significant impact on springtime surface-atmosphere energy exchange in various numerical weather prediction models.

\subsection{Drought and stand thinning}

Besides the seasonal course of climate constraints and physiological activity, transpiration and energy partitioning at boreal forests are strongly influenced by droughts (e.g. Granier et al., 2007; Bernier et al., 2006) and disturbances (e.g. Amiro, 2001; Amiro et al., 2006; Dore et al., 2010). During dry periods stricter control of water use may be needed and is achieved by reduction of transpiration by stomatal closure. During the twelve studied years, longer than a few day periods of drought stress occurred only in 1999 and 2006, the latter being more severe. Duursma et al. (2008) studied how daily transpiration rates were influenced by decreasing $\theta$. They assumed that stomata operate to remain constant minimum leaf water potential to avoid the xylem metabolism and showed that the reduction in transpiration rates occurs rapidly when $\theta$ measured at 5 to $25 \mathrm{~cm}$ depth decreases below $0.15 \mathrm{~m}^{3} \mathrm{~m}^{-3}$ (corresponds to soil water potential around $-0.5 \mathrm{MPa}$ ). Their results indicated almost a complete stomatal closure when $\theta$ reached $\approx 0.10 \mathrm{~m}^{3} \mathrm{~m}^{-3}$. Figure 8 shows that the sensitivity of $g_{\mathrm{s}}$ to $D$ increased only slightly but $g_{\text {sref }}$ decreased by a factor of two in August 2006 compared to typical conditions. The forest floor contribution to stand ET remained unchanged also during the drought (Fig. 9). This suggests that reductions in forest floor transpiration occurred in parallel to the decrease of pine transpiration.

The strong decrease of stomatal conductance and transpiration during the drought in July-August 2006 lead to a larger fraction of available energy to be partitioned to sensible heat, which increased $\beta$ to 3-4 compared to typical value below unity (Fig. 6). Therefore, in terms of energy exchange the drought episodes shift the boreal coniferous forest into "spring phase" that promotes diurnal growth of deep convective boundary layer. A back of an envelope calculation of the feedback of surface energy partitioning on ABL height can be made using a simplified slab model for diurnal evolution of the mixed layer height $\left(z_{i}\right)$ as (Juang et al., 2007):

$\frac{d z_{i}}{d t}=\frac{\overline{w^{\prime} T_{\mathrm{ps}}^{\prime}}-\overline{w^{\prime} T_{\mathrm{pz}_{i}}^{\prime}}}{\gamma z_{i}}$

where $\overline{w^{\prime} T_{\mathrm{ps}}^{\prime}}$ and $\overline{w^{\prime} T_{\mathrm{pz}_{i}}^{\prime}}$ are turbulent sensible heat flux at surface and at top of the mixed layer and $\gamma$ the local lapse rate above the mixed layer top. Setting the entrainment flux $\overline{w^{\prime} T_{\mathrm{pz}_{i}}^{\prime}}$ equal to 0.3 times the surface flux (Kim and Entenkhabi, 1998), $\gamma$ equal to dry-adiabatic lapse rate $\left(9.8 \mathrm{~K} \mathrm{~km}^{-1}\right)$ and parameterizing the nocturnal stable boundary layer height as in Zilitinkevich (1972), can $z_{i}$ be evaluated directly from surface flux data. With these simplified model assumptions, the seasonal cycle of ABL height follows the seasonal course of $H$. Based on the model, ABL height typically reaches $1600 \mathrm{~m}$ on sunny days in May-mid June and around 1000-1200 m in July-August when larger fraction of $R_{\mathrm{a}}$ is consumed in evapotranspiration. During the drought in 2006, reduced transpiration lead to increased sensible heat flux and consequently the ABL height exceeded $1600-1700 \mathrm{~m}$. Thus, a reduction of ET from typical $2.5 \mathrm{~mm}$ to about $1 \mathrm{~mm}$ as in August 2006 would reduce the daily moisture input per unit volume of $\mathrm{ABL}$ from $\approx 2.5 \mathrm{~g} \mathrm{~m}^{-3}$ to $\approx 0.7 \mathrm{~g} \mathrm{~m}^{-3}$ and along with concurrent rise of air temperature increase $D$ posing strong positive feedback that further promotes stomatal closure, reduced transpiration and hence larger $H$. Moreover, the entrainment of dry air above the capping inversion further fortifies the positive feedback.

According to Vesala et al. (2005), the net $\mathrm{CO}_{2}$ exchange, water flux and ozone deposition remained unaltered during the first year after the thinning performed in January-March, 2002. They interpreted the somewhat unexpected finding by that changes in light penetration and among-tree competition increased the stomatal apertures and lead to higher transpiration rates of individual trees and because of this the surface conductance remained unaltered. In addition, due to low light levels at the forest floor the ground vegetation typically operates in the linear part of the photosynthetic light response curve and thus any increase of radiation is likely to enhance understory $\mathrm{CO}_{2}$ assimilation and transpiration in roughly linear fashion (Sevanto et al., 2006; Kolari et al., 2006). Hence, the redistribution of sources and sinks within the forest stand were likely to compensate the reduced needle 
area. Neither in this study were any systematic differences, which could not originate from varying climatic forcing, observed between years 2000-2001 and the first post-thinning years (2002-2003). The aerodynamic conductance, which changes are determined largely by the surface roughness changes, was not significantly altered by the thinning. In addition, influence of $g_{\mathrm{a}}$ is minor compared to stomatal regulation as shown in Fig. 7. The high $g_{\mathrm{s}}$ in 2001 was caused by favorable conditions - frequent recharge of soil water storage by precipitation, average $R_{\mathrm{g}}$ and $T$ that caused $D$ to remain low (Fig. 2) - rather than higher leaf area. The insensitivity of $g_{\mathrm{s}}$ to LAI reduction is in line with the evaporation model of Kelliher et al. (1995) which suggests that the bulk $g_{\text {s }}$ (including forest floor and soil) significantly exceeds the integrated stomatal conductance only when projected LAI is less than $3 \mathrm{~m}^{2} \mathrm{~m}^{-2}$. Vesala et al. (2005) did not either report any changes in summer albedo after the thinning and therefore $R_{\mathrm{n}} / R_{\mathrm{g}}$ ratio and $\beta$ should remain unchanged. The results obtained here support this since both $R_{\mathrm{n}}$ and $H$ scaled similarly to $R_{\mathrm{g}}$ before and after the thinning (Fig. 10, Tables 1 and 2). To summarize, in terms of energy exchange the stand was effectively neutral to the performed forest management.

Also Dore et al. (2010) reported recently that thinning had only a small effect on stand ET. According to them, thinning that decreased the density of a Ponderosa pine stand by $70 \%$, basal area by $35 \%$ and stand LAI by $30 \%$ reduced annual ET only by $13 \%$ in the first year after the thinning compared to their intact reference site. In addition, they did not observe any changes in ecosystem water use efficiency between the reference and managed site, in line with the results Misson et al. (2005) obtained from a young Ponderosa pine plantation. Similarly, Knoche (2005) did not find any reduction of evapotranspiration after thinning of a 66-year old Scots pine stand in Germany.

\subsection{Energy partitioning and inter-annual variability}

The energy exchange above the forest floor was measured only after the years following the thinning and thus the importance of it on the partitioning of energy fluxes between the soil-understory and main canopy could not be explored. The measured contribution of forest floor to the total ecosystem evapotranspiration (20-25\%, Fig. 9) agrees well with the previously reported range from coniferous forests. Constantin et al. (1999) measured understory LE that was about $10 \%$ of the total in a closed-canopied spruce/pine forest during a summer day. In a relative open-canopied old-growth ponderosa pine forest the forest floor/understory contribution was 20-30\% of total ET (Baldocchi and Vogel, 1996) and between 10 and $40 \%$ in a Jack pine stand (Baldocchi et al., 1997). In Siberia, between 33 and $92 \%$ of daily ET was found to originate from a floor of a Scots pine forest (Kelliher et al., 1998). Iida et al. (2009) reported the forest floor component to be $51 \%$ of total ET in a Siberian larch forest during the foliated period and found significant seasonal variability with higher frac- tion in spring before the leaf flushing and in autumn during and after the senescence. On the other hand, they found only little variation during two consecutive years, similarly to the results obtained in this study which indicated that the forest floor ET stays proportional to whole forest ET even in very dry conditions such as 2006 (Fig. 9).

There is wealth of studies on short-term energy exchange of boreal coniferous forests which have indicated that these ecosystems are conservative on their water use and a large fraction of the available energy is redistributed to sensible heat flux. In July-August the $H / R_{\mathrm{n}}$ ratio varied at SMEAR II between 0.21 and $0.49(0.30 \pm 0.07$, mean $\pm \mathrm{std})$ and $\mathrm{LE} / R_{\mathrm{n}}$ from 0.41 to $0.67(0.51 \pm 0.10)$ the summer 2006 (drought) and 2001 (moist) being the two extremes (Table 2). These values compare well to other coniferous ecosystems in boreal region. Namely, Kelliher et al. (1998) observed $H / R_{\mathrm{n}}$ and $\mathrm{LE} / R_{\mathrm{n}}$ ratios 0.52 and 0.48 , respectively, in a Scots pine forest in Siberia while Lindroth (1985) found slightly larger evaporative fraction $\left(\mathrm{LE} / R_{\mathrm{n}} \approx 0.59\right)$ in Sweden at $\approx 60^{\circ} \mathrm{N}$. About half of $R_{\mathrm{n}}$ was consumed to both $H$ and LE in a Black spruce stand in Ontario, Canada (den Hartog et al., 1994), about the same fractions than in Saskatchewan (0.45 to LE and 0.52 to $H$ ) (Jarvis et al., 1997). In an old-growth mixed forest in Norunda, Sweden, Grelle et al. (1997) reported 61\% of $R_{\mathrm{n}}$ to be consumed as $H$ and $38 \%$ as LE. The energy exchange characteristics of boreal vegetation listed above were summarized in Baldocchi et al. (2000). Beringer et al. (2005) observed $H / R_{\mathrm{n}} \approx 0.4$ and $\mathrm{LE} / R_{\mathrm{n}} \approx 0.37$ on a White spruce forest in Alaska. Humphreys et al. (2003) studied coastal Douglas-fir forest in British Columbia and found $\beta$ about 1.1 for the summer with a maximum exceeding 3 in dry conditions. At SMEAR II site the soil heat flux accounted only $5-7 \%$ of $R_{\mathrm{n}}$ in July-August, a similar value to what has been observed before on coniferous forests (Lindroth, 1985; Baldocchi et al., 1997; Jarvis et al., 1997; Kelliher et al., 1997). The storage terms have largest contribution on the energy balance (Eq. 1) during the transition periods in morning and evening hours when their magnitude is comparable to the other terms. Otherwise the storage terms are order of magnitude smaller than $R_{\mathrm{n}}$. In addition, on daily or longer timescales their importance in energy balance vanishes.

No trends were observed in the annual ET which varied less than $15 \%$ around the average value of $327 \mathrm{~mm}$ (in 2000-2008), only slightly more than the observed variability $(<8 \%)$ of GPP in years 2002-2007 (Kolari et al., 2009). It appears that years with high evaporative demand (high $D$ ) were characterized by low surface conductance (Fig. 10) and therefore the evapotranspiration rates remain less variable than would be assumed based on the variability of meteorological conditions. The variability of latent heat exchange could not be related to any specific meteorological parameter, neither over the summer (May-August, Fig. 10) or annually. Because the evaporation rates remain rather stable over the years, any increase in received short-wave radiation predominantly enhances the sensible heat exchange 
and the positive relationship between $R_{\mathrm{g}}$ and $H$ is strong (Fig. 10). The results obtained in this study, the small variability of annual ET in particular, resemble the previous results. Gielen et al. (2010) found annual evapotranspiration of a Scots pine forest in Belgium to vary between $280 \mathrm{~mm}$ and $400 \mathrm{~mm}$ while the precipitation ranged from 650 to $1100 \mathrm{~mm}$. Grünwald and Bernhofer (2007) showed that ET was quite conservative, between 389 and $537 \mathrm{~mm}$ while precipitation varied from 501 to $1098 \mathrm{~mm}$ during 1996-2005 at a sprucedominated coniferous forest located in Tharandt, Germany. At their site annual $\beta$ was typically between $0.6-0.7$ (extremes 0.53 and 1.16) and the highest $\beta$ and lowest ET corresponded to 2003 when an extreme heat wave event occurred in Southern and Central Europe (Granier et al., 2003). In Siberian Scots pine forest, Tchebakova et al. (2002) observed almost no variability of annual ET (around $290 \mathrm{~mm}$ ) for years with similar precipitation (213-228 mm). Over a seven year period, ET from an eastern Siberian larch forest growing on permafrost region showed only moderate variability (169$220 \mathrm{~mm}$ ) compared to precipitation (111-347 mm). During the summer months (June-August) LE accounted for 38$67 \%$ of the sum of turbulent heat fluxes (Ohta et al., 2008). According to them the IAV of ET was caused more by the regulatory processes of the vegetation than by atmospheric demand and they found the soil moisture content to be the most important factor behind the annual variability. The constancy of annual ET and decaying trend of Bowen ratio over the growing season were also confirmed at coniferous Black spruce and Jack pine forests in Canada (Amiro et al., 2006).

\section{Conclusions}

The energy exchange characteristics of a boreal Scots pine forest growing in southern boreal zone in Finland were analyzed from diurnal to inter-annual timescales using a twelveyear dataset acquired by eddy-covariance (EC) accompanied by basic ecological and meteorological measurements. Regarding the four inter-related questions that framed the study objectives the conclusions are:

1. The diurnal and seasonal variability of the energy exchange is predominantly caused by the short-wave radiation input but strongly influenced by the seasonal course of the physiological activity of Scots pine. In wintertime and during clear nights the atmosphere is stably stratified, $H$ towards the ground and the overall magnitude of energy fluxes remains low. In MarchApril, when $R_{\mathrm{g}}$ is already high, the slow recovery of the vegetation from winter dormancy and hence low photosynthetic capacity restricts stomatal conductance and transpiration rates remain low. Consequently, $\beta$ peaks in spring (3-6) and decreases with increasing evapotranspiration towards the summer reaching a typical summer value $(0.7-0.9)$ in July-August. $H$ peaks in MayJune, about two months before LE. The ground heat flux and storage terms are typically order of magnitude smaller than the other terms but become important during morning and evening. On annual timescale the evapotranspiration is rather constant (average $327 \mathrm{~mm}$, variability $<15 \%$ ) and changes in $R_{\mathrm{g}}$ primarily affect the sensible heat exchange. Moreover, seasonal variability of energy partitioning exceeds markedly the interannual. During the twelve-years, only two drought episodes occurred, causing reduced transpiration and concurrently increased of $H$ to springtime levels.

2. The open structure of the stand (total LAI about $7 \mathrm{~m}^{2} \mathrm{~m}^{-2}$ ) allows the forest floor vegetation and soil contribute $18-25 \%$ (average $22 \%$ ) of the total ET over April-October period. This fraction remained constant over wide range of microclimatic conditions, including an intensive drought in 2006. The forest floor contribution was marginally larger (25-30\%) in spring, especially during years with early snowmelt, and decreased towards autumn.

3. The surface energy balance could not be closed with the micrometeorological measurements and the closure varied between 0.66 and 0.95 . The three first years (19971999) had significantly poorer closure, presumably because of underestimated LE. The energy balance closure exhibited strong seasonal course: the spring months associated with large $H$ (which promotes growth of deep convective boundary layer) were characterized by poorer closure than late summer when LE formed an important part of energy budget.

4. The stomatal regulation has pronounced effect on surface energy partitioning in spring when the vegetation is recovering from the winter and during infrequent drought episodes. The aggregated response of all stomata were analyzed in terms of "big-leaf" $g_{\mathrm{s}}$ inverted from EC measurements and the sensitivity to ambient vapor pressure deficit $(D)$ was evaluated based on the model proposed by Oren et al. (1999). The sensitivity to $D$ remained rather constant over the whole season, increased only slightly during the intense drought in 2006 and was in close agreement to variety of species analyzed in Oren et al. (1999). The reference conductance, which describes the aperture of the stomata at $D=1 \mathrm{kPa}$, had minimum value in early spring, increased gradually and exceeded the spring values twothree fold in July-August. During drought the reference conductance decreased markedly. The drought-induced reduction of transpiration occurred when $\theta$ decreased below $\approx 0.15 \mathrm{~m}^{3} \mathrm{~m}^{-3}$. 
Acknowledgements. The multi-year dataset analyzed in this paper could not have been collected without considerable efforts of several people working at the SMEAR II-station. Especially, Veijo Hiltunen, Erkki Siivola and Toivo Pohja are acknowledged for planning and maintaining the measurements and Petri Keronen for his valuable work on quality control of the eddy-covariance and meteorological data utilized in this paper. I am grateful to Timo Vesala and Pasi Kolari for creative and critical comments and Tiia Grönholm for proof-reading. The Finnish Meteorological Institute is acknowledged for providing the precipitation data measured at Hyytiälä station. The financial support by the Academy of Finland Centre of Excellence program (project no 1118615) is gratefully acknowledged along EU projects IMECC and ICOS.

Edited by: E. Falge

\section{References}

Amiro, B. D.: Paired-tower measurements of carbon and energy fluxes following disturbance in the boreal forest, Glob. Change Biol., 7, 253-268, 2001.

Amiro, B. D., Barr, A. G., Black, T. A., Iwashita, H., Kljun, N., McCaughey, J. H., Morgenstern, K., Murayama, S., Nesic, Z., Orchansky, A. L., and Saigusa, N.: Carbon, energy and water fluxes at mature and disturbed forest sites, Saskatchewan, Canada, Agr. Forest Meteorol., 136, 237-251, 2006.

Arain, M. A., Black, T. A., Barr, A. G., Griffis, T. J., Morgenstern, K., and Nesic, Z.: Year-round observations of the energy and water vapour fluxes above a boreal black spruce forest, Hydrol. Process., 17, 3581-3600, 2003.

Arneth, A., Lloyd, J., Shibistova, O., Sogachev, A., and Kolle, O.: Spring in the boreal environment: observations on pre- and postmelt energy and $\mathrm{CO}_{2}$ fluxes in two central Siberian ecosystems, Boreal Environ. Res., 11, 311-328, 2006.

Aubinet, M., Grelle, A., Ibrom, A., Rannik, Ü., Monchrieff, J., Foken, T., Kowalski, A. S., Martin, P. H., Bergibier, P., Bernhofer, C., Clement, R., Elbers, J., Granier, A., Grünwald, T., Morgenstern, K., Pilegaard, K., Rebmann, C., Snicders, W., Valentini, R., and Vesala, T.: Estimates of the Annual Net Carbon and Water Exchange of Forests: The EUROFLUX Methodology, Adv. Ecol. Res., 30, 113-178, 2000.

Baldocchi, D. D.: Turner review no. 15: "Breathing" the terrestrial biosphere: lessons learned from a global network of carbon dioxide flux measurement systems, Aust. J. Bot., 56, 1-26, 2008.

Baldocci, D. D. and Vogel, C. A.: Energy and $\mathrm{CO}_{2}$ flux densities above and below a temperate broad-leaved forest and a boreal pine forest, Tree Physiol., 16, 5-16, 1996.

Baldocci, D. D., Vogel, C. A., and Hall, B.: Seasonal variation of carbon dioxide exchange rates above and below a boreal Jack pine forest, Agr. Forest Meteorol., 83, 147-170, 1997.

Baldocchi, D. D., Kelliher, F. M., Black, T. A., and Jarvis, P.: Climate and vegetation controls on boreal zone energy exchange, Glob. Change Biol., 6 (Suppl. 1), 69-83, 2000.

Ball, J. T., Woodrow, I. E., and Berry, J. A.: A model predicting stomatal conductance and its contribution to the control of photosynthesis under different environmental conditions, in: Progress in Photosyntehsis Research, edited by: Biggens, J., Martinus Nijhoff, CZ Zoetermeer, Netherlands, 221-224, 1987.
Beer, C., Ciais, P., Reichstein, M., Baldocchi, D., Law, B. E., Papale, D., Soussana, J.-F., Amman, C., Buchmann, N., Frank, D., Gianelle, D., Janssens, I. A., Knohl, A., Köstner, B., Moors, E., Roupsard, O., Verbeeck, H., Vesala, T., Williams, C. A., and Wohlfart, G.: Temporal and among-site variability of inherent water use efficiency at the ecosystem level, Global Biogeochem. Cy., 23, GB2018, doi:10.1029/2008GB003233, 2009.

Bergh, J. and Linder, S.: Effects of soil warming during spring on photosynthetic recovery in boreal Norway spruce stands, Glob. Change Biol., 5, 245-253, 1999.

Bergh J., McMurtrie, R. E., and Linder, S.: Climatic factors controlling the productivity of Norway spruce: A model-based analysis, Forest Ecol. Manag., 1110, 127-139, 1998.

Bernier, P. Y., Bartlett, P., Black, T. A., Barr, A., Kljun, N., and McCaughley, J. H.: Drought constraints on transpiration and canopy conductance in mature aspen and jack pine stands, Agr. Forest Meteorol., 140, 64-78, 2006.

Beringer, J., Chapin, F. S. III, Thompson, C. C., and McGuire, A. D.: Surface energy exchange salong a tundra-forest transition and feedbacks to climate, Agr. Forest Meteorol., 131, 143-161, 2005.

Blanken, P. D., Black, T. A., Yang, P. C., Neumann, H. H., Nesic, Z., Staebler, R., den Hartog, G., Novak, M. D., and Lee, X.: Energy balance and canopy conductance of a boreal aspen forest: Partitioning overstory and understory components, J. Geophys. Res.-Atmos., 102, 28915-28927, 1997.

Chapin, F. S., McGuire, A. D., Randerson, J., Pielke, R., Baldocchi, D., Hobbie, S. E., Roulet, N., Eugster, W., Kasischke, E., Rastetter, E. B., Zimov, S. A., and Running, S. W.: Arctic and boreal ecosystems of western North America as components of the climate system, Glob. Change Biol., 6, 211-223, 2000.

Christensen, J. H., Hewitson, B., Busuioc, A., Chen, A., Gao, X., Held, I., Jones, R., Kolli, R. K., Kwon, W.-T., Laprise, R., Magaña Rueda, V., Mearns, L., Menéndez, C. G., Räisänen, J., Rinke, A., Sarr, A., and Whetton, P.: Regional Climate Projections, in: Climate Change 2007: The Physical Science Basis. Contribution of Working Group I to the Fourth Assessment Report of the Intergovernmental Panel on Climate Change, edited by: Solomon, S., Qin, D., Manning, M., Chen, Z., Marquis, M., Averyt, K. B., Tignor, M., and Miller, H. L., Cambridge University Press, Cambridge, United Kingdom and New York, NY, US, 2007.

Constantin, J., Grelle, A., Ibrom, A., and Morgenstern, K.: Flux partitioning between understorey and overstorey in a boreal spruce/pine forest determined by the eddy covariance method, Agr. Forest Meteorol., 98-99, 629-643, 1999.

Cowan, I. R. and Farquhar, G. D.: Stomatal function in relation to leaf metabolism and environment, Sym. Soc. Exp. Biol., 31, 471-505, 1977.

den Hartog, G., Neumann, H. H., King, K. M., and Chipanski, A. C.: Energy budget measurements using eddy correlation and Bowen ratio techniques at the Kinosheo Lake tower site during the Northern Wetlands Study, J. Geophys. Res.-Atmos., 99, 1539-1549, 1994.

Dore, S., Kolb, T. E., Montes-Helu, M., Eckert, S. E, Sullivan, B. W., Hungate, B. A., Kaye, J. P., Hart, S. C., Koch, G. W., and Finkral, A.: Carbon and water fluxes from ponderosa pine forests disturbed by wildfire and thinning, Ecol. Appl., 20, 663-683, 2010. 
Drebs, A., Nordlund, A., Karlsson, P., Helminen, J., and Rissanen, P.: Tilastoja Suomen ilmastosta 1971-2000 (Climatological Statistics of Finland 1971-2000), Finnish Meteorological Institute, 2002.

Duursma, R. A., Kolari, P., Perämäki, M., Nikinmaa, E., Hari, P., Delzon, S., Loustau, D., Ilvesniemi, H., Pumpanen, J., and Mäkelä, A.: Predicting the decline in daily maximum transpiration rate of two pine stands during drought based on constant minimum leaf water potential and plant hydraulic conductivity, Tree Physiol., 28, 265-276, 2008.

Eugster, W., Rouse, W. R., Pielke, R. A., McFadden, J. P., Baldocchi, D. D., Kittel, T. G. F., Chapin, F. S., Liston, G. E., Vidale, P. L., Vaganov, E., and Chambers, S.: Land-atmosphere energy exchange in Arctic tundra and boreal forest: available data and feedbacks to climate, Glob. Change Biol., 6 (Suppl. 1), 84-115, 2000.

FAO-UNESCO-ISRIC: Soil map of the world, Revised legend, World Soil Resources Report no. 60, UNESCO, Rome, 1990.

Foken, T.: The energy balance closure problem: an overview, Ecol. Appl., 18(6), 1351-1367, 2008.

Granier, A., Reichstein, M., Breda, A., Janssens, I. A., Falge, E., Ciais, P., Grünwald, T., Aubinet, M., Berbigier, P., Bernhofer, C., Buchmann, N., Facini, O., Grassi, G., Heinesch, B., Ilvesniemi, H., Keronen, P., Knohl, A., Köstner, B., Lagergren, F., Lindroth, A., Longdoz, B., Loustau, D., Mateus, J., Montagnanni, L., Nys, C., Moors, E., Papale, D., Peiffer, M., Pilegaard, K., Pita, G., Pumpanen, J., Rambal, S., Rebamn, C., Rodrigues, A., Seuert, G., Tenhunen, J., Vesala, T., and Wang, Q.: Evidence on soil water control on carbon and water dynamics in European forests during the extremely dry year: 2003, Agr. Forest Meteorol., 143, 123-145, 2003.

Gielen, B., Verbeeck, H., Neirynck, J., Sampson, D. A., Vermeiren, F., and Janssens, I. A.: Decadal water balance of a temperate Scots pine forest (Pinus sylvestris L.) based on measurements and modelling, Biogeosciences, 7, 1247-1261, doi:10.5194/bg7-1247-2010, 2010.

Grelle, A., Lundberg, A., Lindroth, A., Moren, A. S., and Cienciala, E.: Evaporation components of boreal forest: variations during the growing season, J. Hydrol., 197, 70-87, 1997.

Grunwald, T. and Bernhofer, C.: A decade of carbon, water and energy flux measurements of an old spruce forest at the Anchor Station Tharandt, Tellus, 59B, 387-396, 2007.

Göckede, M., Foken, T., Aubinet, M., Aurela, M., Banza, J., Bernhofer, C., Bonnefond, J. M., Brunet, Y., Carrara, A., Clement, R., Dellwik, E., Elbers, J., Eugster, W., Fuhrer, J., Granier, A., Grünwald, T., Heinesch, B., Janssens, I. A., Knohl, A., Koeble, R., Laurila, T., Longdoz, B., Manca, G., Marek, M., Markkanen, T., Mateus, J., Matteucci, G., Mauder, M., Migliavacca, M., Minerbi, S., Moncrieff, J., Montagnani, L., Moors, E., Ourcival, J.-M., Papale, D., Pereira, J., Pilegaard, K., Pita, G., Rambal, S., Rebmann, C., Rodrigues, A., Rotenberg, E., Sanz, M. J., Sedlak, P., Seufert, G., Siebicke, L., Soussana, J. F., Valentini, R., Vesala, T., Verbeeck, H., and Yakir, D.: Quality control of CarboEurope flux data - Part 1: Coupling footprint analyses with flux data quality assessment to evaluate sites in forest ecosystems, Biogeosciences, 5, 433-450, doi:10.5194/bg-5-433-2008, 2008.

Halldin, S., Grip, H., Jansson, P. E., and Lindgren, A.: Micrometeorology and hydrology of a pine forest ecosystems. II. Theory and models, in: Structure and function of northern coniferous forests - an ecosystem study, edited by: Person, T., Ecol. Bull. (Stockholm), 32, 463-503, 1980.

Hari, P. and Kulmala, L. (Eds.): Boreal forest and climate change, Springer, ISBN 978-1-4020-8717-2, 2008.

Hari, P. and Kulmala, M.: Station for measuring ecosystematmosphere relations (SMEAR II), Boreal Environ. Res., 10, 315-322, 2005.

Hari, P., Mäkelä, A., Kospilahti, E., and Holmberg, M.: Optimal control of gas exchange, Tree Physiol., 2, 169-175, 1986.

Humphreys, E. R., Black, T. A., Ethier, G. J., Drewitt, G. B., Spittlehouse, D. L., Jork, E.-M., Nesic, Z., and Livingston, N. J.: Annual and seasonal variability of sensible and latent heat fluxes above a costal Douglas fir forest, British Columbia, Canada, Agr. Forest Meteorol., 115, 109-125, 2003.

Iida, S., Ohta, T., Matsumoto, K., Nakai, T., Kuwada, T., Kononov, A. V., Maximov, T. C., van der Molen, M. K., Dolman, H., Tanaka, H., and Yabuki, H.: Evapotranspiration from understory vegetation in ana eastern Siberian boreal larch forest, Agr. Forest Meteorol., 149, 1129-1139, 2009.

Ilvesniemi, H., Pumpanen, J., Duursma, R., Hari, P., Keronen, P., Kolari, P., Kulmala, M., Mammarella, I., Nikinmaa, E., Rannik, Ü., Pohja, T., Siivola, E., and Vesala, T.: Water balance of a boreal Scots pine forest, Boreal Environ. Res., 15, 375-396, 2010.

Jarvis, P. G.: The interpretation of the variations in leaf water potential and stomatal conductance found in canopies in the field, Philos. T. Roy. Soc. B, 273, 593-610, 1976.

Jarvis, P. G. and McNaughton, K. G.: Stomatal control of transpiration: scaling up from leaf to region, Adv. Ecol. Res., 15, 1-49, 1986.

Jarvis, P. G., Massheder, J. M., Hale, S. E., Moncrieff, J. B., Rayment, M., and Scott, S. L.: Seasonal variation of carbon dioxide, water vapor, and energy exchange of boreal black spruce forest, J. Geophys. Res.-Atmos., 102, 28953-28966, 1997.

Juang, J.-Y., Porporato, A., Stoy, P., Siqueira, M. S., Oishi, A. C., Detto, M., Kim, H. S., and Katul, G. G.: Hydrologic and atmospheric controls on initiation of convective precipitation events, Water Resour. Res., 43, W03421, doi:10.1029/2006WR004954, 2007.

Katul, G. G., Palmroth, S., and Oren, R.: Leaf stomatal responses to vapor pressure deficit under current and $\mathrm{CO}_{2}$-enriched atmosphere explained by economics of gas exchange, Plant Cell Environ., 32, 968-979, 2009.

Kelliher, F. M., Leuning, R., Raupach, M. R., and Schulze, E.-D.: Maximum conductances for evaporation from global vegetation types, Agr. Forest Meteorol., 73, 1-16, 1995.

Kelliher, F. M., Hollinger, D. Y., Schulze, E. D., Vygodskaya, N. N., Byers, J. N., Hunt, J. E. McSeveny, T. M., Milukova, I., Sogatchev, A., Varlagin, A., Ziegler, W., Arneth, A., and Bauer, B.: Evaporation from a Siberian larch forest, Agr. Forest Meteorol., 85, 135-147, 1997.

Kelliher, F. M., Lloyd, J., Arneth, A., Byers, J. N., McSeveny, T. M., Milukova, I., Grigoriev, S., Panfyorov, M., Sogatchev, A., Varlagin, A., Ziegler, W., Auer, G., and Schulze, E.-D.: Evaporation from a central Siberian pine forest, J. Hydrol., 205, 279-296, 1998.

Kim, C. P. and Entekhabi, D.: Feedbacks in the land-surface and mixed-layer energy budgets, Bound.-Lay. Meteorol., 88, 1-21, 1998. 
Knoche, D.: Effects of stand conversion by thinning and underplanting on water and element fluxes of a pine ecosystem $(P$. sylvestris L.) on lignite mine spoil, Forest Ecol. Manag., 212, 214-220, 2005.

Kolari, P., Pumpanen, J., Kulmala, L., Ilvesniemi, H., Nikinmaa, E., Grönholm, T., and Hari, P.: Forest floor vegetation plays an important role in photosynthetic production of boreal forests, Forest Ecol. Manag., 221, 241-248, 2006.

Kolari, P., Lappalainen, H., Hänninen, H., and Hari, P.: Relationship between temperature and the seasonal course of photosynthesis in Scots pine at northern timberline and southern boreal forest, Tellus, 59B, 542-552, 2007.

Kolari, P., Kulmala, L., Pumpanen, J., Launiainen, S., Ilvesniemi, H., Hari, P., and Nikinmaa, E.: $\mathrm{CO}_{2}$ exchange and component $\mathrm{CO}_{2}$ fluxes of a boreal Scots pine forest, Boreal Environ. Res., 14, 761-783, 2009.

Kulmala, L., Launiainen, S., Pumpanen, J., Lankreijer, H., Lindroth, A., Hari, P., and Vesala, T.: $\mathrm{H}_{2} \mathrm{O}$ and $\mathrm{CO}_{2}$ fluxes at the floor of a boreal pine forest, Tellus, 60B, 167-178, 2008.

Laubach, J. and McNaughton, K. G.: A spectrum-independent procedure for correcting eddy fluxes measured with separated sensors, Bound.-Lay. Meteorol., 89, 445-467, 1999.

Launiainen, S., Rinne, J., Pumpanen, J., Kulmala, L., Kolari, P., Keronen, P., Siivola, E., Pohja, T., Hari, P., and Vesala, T.: Eddy covariance measurements of $\mathrm{CO}_{2}$ and sensible and latent heat fluxes during a full year in a boreal pine forest trunk-space, Boreal Environ. Res., 10, 569-588, 2005.

Launiainen, S., Vesala, T., Mölder, M., Mammarella, I., Smolander, S., Rannik, Ü., Kolari, P., Hari, P., Lindroth, A., and Katul, G. G.: Vertical variability and effect of stability on turbulence characteristics down to the floor of a pine forest, Tellus, 59B, 919-936, 2007.

Launiainen, S., Sevanto, S., Mäkelä, A., and Vesala, T.: Jarvis-type model for dry-canopy surface conductance: seasonal variation, Report Series in Aerosol Science, 102, 233-238, available at: http://www.atm.helsinki.fi/FAAR/reportseries/rs-102.pdf, 2009.

Law, B. E., Falge, E., Gu, L., Baldocchi, D. D., Bakwin, P., Berbigier, P., Davis, K., Dolman, A. J., Falk, M., Fuentes, J. D., Goldstein, A., Granier, A., Grelle, A., Hollinger, D., Janssens, I. A., Jarvis, P., Jensen, N. O., Katul, G. G., Mahli, Y., Matteucci, G., Meyers, T., Monson, R., Munger, W., Oechel, W., Olson, R., Pilegaard, K., Paw, K. T., Thorgeirsson, H., Valentini, R., Verma, S., Vesala, T., Wilson, K., and Wofsy, S.: Environmental controls over carbon dioxide and water vapor exchange of terrestrial vegetation, Agr. Forest Meteorol., 113, 97-120, 2002.

Lindroth, A.: Seasonal and diurnal variation of energy budget components in coniferous forests, J. Hydrol., 82, 1-15, 1985.

Lindroth, A., Mölder, M., and Lagergren, F.: Heat storage in forest biomass improves energy balance closure, Biogeosciences, 7 , 301-313, doi:10.5194/bg-7-301-2010, 2010.

Mammarella, I., Launiainen, S., Grönholm, T., Keronen, P., Pumpanen, J., Rannik, Ü., and Vesala, T.: Relative humidity effect on high-frequency attenuation of water vapor flux measured by a closed-path eddy-covariance system, J. Atmos. Ocean. Tech., 26, 1856-1866, 2009.

Markkanen, T., Rannik, Ü., Keronen, P., Suni, T., and Vesala, T.: Eddy covariance fluxes over a boreal Scots pine forest, Boreal Environ. Res., 6, 65-78, 2001.

Misson, L., Tang, J., Xu, M., McKay, M., and Goldstein, A. H.: In- fluences of recovery from clear-cut, climate variability, and thinning on the carbon balance of a young ponderosa pine plantation, Agr. Forest Meteorol., 130, 207-222, 2005.

Moderow, U., Aubinet, M., Feigenwinter, C., Kolle, O., Lindroth, A., Mölder, M., Montagnani, L., Rebman, C., and Bernhofer, C.: Available energy and energy balance closure at four coniferous sites accross Europe, Theor. Appl. Climatol., 98, 397-412, 2009.

Monteith, J. L. and Unsworth, M.: Principles of Environmental Physics, 3rd edition, Academic Press, ISBN 978-0-12-5051033, 2008.

Moore, C. J.: Frequency-response corrections for eddy-correlation systems, Bound.-Lay. Meteorol., 37, 17-35, 1986.

Mäkelä, A., Hari, P., Berninger, F., Hänninen, H., and Nikinmaa, E.: Acclimation of photosynthetic capacity in Scots pine on the annual cycle of temperature, Tree Physiol., 24, 369-378, 2004.

Mäkelä, A., Kolari, P., Karimäki, J., Nikinmaa, E., Perämäki, M., and Hari, P.: Modeling five years of weather-driven variation of GPP in a boreal forest, Agr. Forest Meteorol., 139, 382-398, 2006.

Mäkelä, A., Pulkkinen, M., Kolari, P., Lagergren, F., Berbigier, P., Lindroth, A., Loustau, D., Nikinmaa, E., Vesala, T., and Hari, P.: Developing an empirical model of stand GPP with the LUE approach: analysis of eddy covariance data at five contrasting conifer sites in Europe, Glob. Change Biol., 14, 92-108, 2008.

Ochsner, T. E., Sauer, T. J., and Horton, R.: Soil heat storage measurement in energy balance studies, Agron. J., 99, 311-319, 2007.

Ohta, T., Maximov, T. C., Dolman, A. J., Nakai, T., van der Molen, M. K., Konov, A. V., Maximov, A. P., Hiyama, T., Iijima, Y., Moors, E. J., Tanaka, H., Toba, T., and Yabuki, H.: Interannual variation of water balance and summer evapotranspiration in an eastern Siberian larch forest over a 7-year period (1998-2006), Agr. Forest Meteorol., 148, 1941-1593, 2008.

Oliphant, A. J., Grimmond, C. S. B., Zutter, H. N., Schmid, H. P., Su, H.-B., Scott, S. L., Offerle, B., Randolph, J. C., and Ehman, J.: Heat storage and energy balance fluxes for a temperate deciduous forest, Agr. Forest Meteorol., 126, 185-201, 2004.

Oren, R., Sperry, J. S., Katul, G. G., Pataki, D. E., Ewers, B. E., Phillips, N., and Shafer, K. V. R.: Survey and synthesis of intraand inter-specific variation in stomatal sensitivity to vapor pressure deficit, Plant Cell Environ., 22, 1515-1526, 1999.

Pelkonen, P. and Hari, P.: The dependence of springtime recovery of $\mathrm{CO}_{2}$ uptake in Scots pine on temperature and internal factors, Flora, 169, 398-404, 1980.

Priestley, C. H. B. and Taylor, R. J.: On the assessment of surface heat flux and evaporation using large-scale parameters, Mon. Weather Rev., 100, 81-92, 1972.

Rannik, Ü.: On the surface layer similarity at a complex forest site, J. Geophys. Res.-Atmos., 103, 8685-8697, 1998.

Rannik, Ü., Keronen, P., Hari, P., and Vesala, T.: Estimation of forest-atmosphere $\mathrm{CO}_{2}$ exchange by eddy covariance and profile techniques, Agr. Forest Meteorol., 126, 141-155, 2004.

Reichstein, M., Falge, E., Baldocchi, D., Papale, D., Aubinet, M., Berbigier, P., Bernhofer, C., Buchmann, N., Gilmanov, T., Granier, A., Grünwald, T., Havránková, K., Ilvesniemi, H., Janous, D., Knohl, A., Laurila, T., Lohila, A., Loustau, D., Matteucci, G., Meyers, T., Miglietta, F., Ourcival, J.-M., Pumpanen, J., Rambal, S., Rotenberg, E., Sanz, M., Tenhunen, J., Seufert, G., Vaccari, F., Vesala, T., Yakir, D., and Valentini, R.: On 
the separation of net ecosystem exchange into assimilation and ecosystem respiration: review and improved algorithm, Glob. Change Biol., 11, 1424-1439, 2005.

Sevanto, S., Suni, T., Pumpanen, J., Grönholm, T., Kolari, P., Nikinmaa, E., Hari, P., and Vesala, T.: Wintertime photosynthesis and water uptake in a boreal forest, Tree Physiol., 26, 749-757, 2006.

Sogachev, A., Rannik, Ü., and Vesala, T.: Flux footprints over complex terrain covered by heterogenous forest, Agr. Forest Meteorol., 127, 142-158, 2004.

Suni, T., Rinne, J., Rannik, Ü., Reissell, A., Altimir, N., Keronen, P., Rannik, Ü., Dal Maso, M., Kulmala, M., and Vesala, T.: Longterm measurements of surface fluxes above a Scots pine forest in Hyytiälä, southern Finland, 1996-2001, Boreal Environ. Res., 8, 287-302, 2003.

Tchebakova, N. M., Kolle, O., Zolotoukhine, D., Arneth, A., Styles, J. M., Vygodskaya, N. N., Schultze, E.-D., Shibistova, O., and Lloyd, J.: Inter-annual and seasonal variations of energy and water vapour fluxes above a Pinus sylvestris forest in Siberian middle taiga, Tellus, 54B, 537-551, 2002.

Thum, T., Aalto, T., Laurila, T., Aurela, M., Kolari, P., and Hari, P.: Parameterization of two photosynthesis models at the canopy scale in a northern boreal Scots pine forest, Tellus, 59B, 874890, 2007.

Teskey, R. O., Hinckley, T. M., and Grier, C. C.: Temperature induced change in water relations of Abies amabilis (Dougl. Forbes), Plant Physiol., 74, 77-80, 1984.

Turnipseed, A. A., Blanken, P. D., Anderson, D. E., and Monson, R. K.: Energy budget above a high-elevation subalpine forest in complex topography, Agr. Forest Meteorol., 110, 177-201, 2002.

Vesala, T., Suni, T., Rannik, Ü., Keronen, P., Markkanen, T., Sevanto, S., Grönholm, T., Smolander, S., Kulmala, M., Ilvesniemi, H., Ojansuu, R., Uotila, A., Levula, J., Mäkelä, A., Pumpanen, J., Kolari, P., Kulmala, L., Altimir, N., Berninger, F., Nikinmaa, E., and Hari, P.: The effect of thinning on surface fluxes in a boreal forest, Global Biogeochem. Cy., 19, GB2001, doi:10.1029/2004GB002316, 2005.
Vesala, T., Launiainen, S., Kolari, P., Pumpanen, J., Sevanto, S., Hari, P., Nikinmaa, E., Kaski, P., Mannila, H., Ukkonen, E., Piao, S. L., and Ciais, P.: Autumn temperature and carbon balance of a boreal Scots pine forest in Southern Finland, Biogeosciences, 7, 163-176, doi:10.5194/bg-7-163-2010, 2010.

Verma, S. B.: Aerodynamic resistances for transfer of mass, heat and momentum, in: Estimation of Aerial Evapotranspiration (Proceedings of a workshop held at Vancouver, B.C. Canada, August 1987), IAHS Publ. no. 177, 1989.

Wilson, K. B., Baldocchi, D. D., Aubinet, M., Berbigier, P., Bernhofer, C., Dolman, H., Falge, E., Field, C., Goldstein, A., Granier, A., Grelle, A., Halldor, T., Hollinger, D., Katul, G., Law, B. E., Lindroth, A., Meyers, T., Moncrieff, J., Monson, R., Oechel, W., Tenhunen, J., Valentini, R., Verma, S., Vesala, T., and Wofsy, S.: Energy partitioning between latent and sensible heat flux during the warm season at FLUXNET sites, Water Resour. Res., 38(12), 1294, doi:10.1029/2001WR000989, 2002a.

Wilson, K., Goldstein, A., Falge, A., Aubinet, M., Baldocchi, D., Berbigier, P., Bernhofer, C., Ceulemans, R., Dolman, H., Field, C., Grelle, A., Ibrom, A., Law, B. E., Kowalski, A., Meyers, T., Moncrieff, J., Monson, R., Oechel, W., Tenhunen, J., Valentini, R., and Verma, S.: Energy balance closure at FLUXNET sites, Agr. Forest Meteorol., 113, 223-243, 2002b.

Zilitinkevich, S. S.: On the determination of the height of the Ekman boundary layer, Bound.-Lay. Meteorol., 3, 141-145, 1972. 